Essay

\title{
What Is Wrong with Inflicting Shame Sanctions?
}

\author{
James Q. Whitman ${ }^{\dagger}$
}

We are all aware that there was a time in the western world when punishment frequently revolved around the public humiliation of the offender. Everyone likes to read about the picturesque barbarism of the old punishments: the pillory, the stocks, the ducking stool, branding, and so on.' Many of us are also dimly aware that such shame sanctions continue to be used in much of the nonwestern world. It is common knowledge. for example, that public humiliation of a dramatic sort was featured in the law of Maoist China; its rituals of self-criticism, public admonition. and public exposure of offenders are well known. ${ }^{2}$ It is also widely known that such shame sanctions have continued to feature in the practice of the People's Republic." where "economic" criminals may still be trucked around town wearing signs describing their offenses. ${ }^{+}$Many countries other than China are known for

$\div$ Ford Foundation Professor of Comparatue and Foreign Lau. Yale Luw Sclwool Earlter serstons of this Essay were presented to faculty worhshops at the Liniversite de Cergy-Pontoise, the Liniversity of Pennsylvania Law School. and the Yale Lau School My thanhs to the participants at all three gatherings for their comments. I also owe particular thanhs to Bruce Acherman. Olisier Beaud. Bill Euald. Henry Hansmann, Dan Kahan. Toni Massaro. Enc Posncr. Richurd Posner. Peter Schuch. Vichı Schultz. Jonathan Simon, Bill Stuntz, and Gillıan Stern Whitman.

1. For a typically quaint introduction to the subject, see WILLIAY AVDREMS. BICONE PL VISHMENTS (2d ed. 1931).

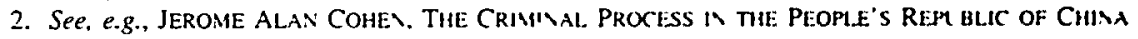
1949-1963, at 20.21 (1968).

3. Article 32 of the 1979 Chınese Crumınal Code, for example. provided that "moral" sanctions could accompany other penal sanctions in certan instances. Sec The Crimmal Lan of the Prople 's Republic of China (Jerome Cohen trans.), 73 J. CRIM. L. \& CRIMINOLOGY 138. 14 (1982), see also Dominque TC Wang, La peine en Chne comemporame, in 4 LA PEIVE 387. 401-02 (Transactions of the Jean Bodin Soc'y for Comparative Institutional History No. 58. 1991) (discussing Anicle 32 of the 1979 Chınese Crumınal Code).

4. Jerome Cohen, Lecture at the Yale Law. School (Oct 21. 1997) I am in no position to judge how this practice may change with the very recent revision of the Chinese Cninunal Code See Seth Faison, Chinese Revise Criminal Code. Not Its Essence. N.Y TIMEs. Mar 7. 1997, at Al For other Chinese phenomena that seem, to the western eye, to belong to a typically shame-sanction-onented system. see. for example, Anne Namam. Taking It to the Screens: Betyng T $V^{\prime}$ Confronts the Cin's Sireet Cromenals. ASIAWEEK, July 19.1996, at 26. which discusses Chinese teleission programs that expose law breakers: and 
employing such practices as well. ${ }^{5}$ Most recently, the media have focused on the humiliation rituals of the Islamic legal revival broadly, and of the Afghan Taliban, in particular. ${ }^{6}$

The scattered reappearance of shame sanctions in the United States is a surprise, however. Most of us, at least as of 1975 or so, would probably have said that sanctions of the premodern type-sanctions whose main purpose is the ritualized humiliation of the offender-had permanently vanished from our legal landscape. ${ }^{7}$ Yet, as news magazines and newspapers have eagerly been reporting, just such sanctions have begun to reappear. ${ }^{8}$ It is true that these practices do not often assume the lurid shapes they took in the early-modern or Maoist worlds. In particular, modern American shame sanctions lack the air of physical violence that has commonly hung about the shame sanctions of other times and places; American courts do not order offenders flogged, dunked, or branded. The current American practice takes milder forms, such as requiring offenders to wear shirts describing their crimes, ${ }^{9}$ publishing the names of prostitutes' johns, ${ }^{10}$ or (in a ritual not that far removed from the Chinese one) making offenders sit outside public courthouses wearing placards. "Unlike the premodern punishments, none of these is inflicted in the expectation that offenders will be physically assaulted. Perhaps the new

Patrick E. Tyler, Crime (and Punishment) Rages Anew in China, N.Y. TIMES, July 11, 1996, at A1, which documents the rise of public punishments.

5. For a convenient compendium of nonwestern practices generally, see 4 LA PEINE, supra note 3. For a discussion of public punishment in early-modem Germany, see RICHARD VAN DULMEN, THEATRE OF HORROR 42-57 (Elisabeth Neu trans., Polity Press 1990) (1985). For a discussion of such punishment in late 18th-century Philadelphia, see MiChaEl MERANZE, LABORATORIES OF VirTUE 19-54 (1996). Other literature is cited throughout this Essay.

6. See, e.g., Terence White, Man Accused of Illicit Sex Paraded Through Kabul Sireets, Agence France Presse, Dec. 14, 1996, available in LEXIS, News Library, AFP File; Terence White, Taliban Parade Arrested Gamblers in Public with Blackened Faces, Agence France Presse, Nov. 30, 1996, available in LEXIS, News Library, AFP File. For an anecdotal account of shame sanctions in Iran, sec Manuchchr Sanadjian, A Public Flogging in South-Western Iran: Juridical Rule, Abolition of Legality and Local Resistance, in INSIDE AND OUTSIDE THE LAW 157, 157-68 (Olivia Harris ed., 1996).

7. One might have thought that the abolition of public whipping for most crimes in Delaware in 1972. see Act of July 6, 1972, ch. 497, 58 Del. Laws 1611, marked the final decline of the old tradition. For a discussion of the early traditions of public punishment in the United States, see generally LAWRENCE $M$. FRIEDMAN, CRIME AND PUNISHMENT IN AMERICAN HISTORY (1993). The one arena in which we do not expect honor-based punishments to vanish is military law. Although I do not discuss military law in this Essay, any full account of the history of shame sanctions in the western world would have to give attention to it.

8. See, e.g., Jonathan Alter \& Pat Wingert, The Return of Shame, NewsweEk, Feb. 6, 1995, at 21; Beverly Shepard, A Public Slap on the Wrist, ATLANTA J. \& CONST., Oct. 19, 1991, at C1; Joseph R. Tybor, Unusually Creative Judges Now Believe Some Punishments Can Fit the Times, CH1. TRIB., July 3, $1988, \S 3$, at 1.

9. See, e.g., Creative Sentence Given to Shoplifter, SAN DIEGo UNION-TRIB., July 2, 1992, at A3.

10. See Courtney Guyton Persons, Note, Sex in the Sunlight: The Effectiveness, Efficiency, Constitutionality, and Advisability of Publishing Names and Pictures of Prostitutes' Patrons, 49 VAND. L. REV. 1525, 1536-37 (1997) (documenting the common use of stigmatizing sanctions to punish prostitutes" customers).

11. See, e.g., Across the USA: News from Every State, USA TODAY, Apr. 22, 1993, at 8A (discussing a South Carolina man sentenced to sit outside the courthouse with a sign reading. "I am a Drunk Driver"). 
shame sanctions seem more acceptable for that reason. Nevertheless, they do not seem very acceptable. But why not?

In this Essay, I want to begin by admitting the truth that our familiar liberal traditions do not give us any persuasive answer to this question. It may seem intuitively obvious that shame sanctions are barbaric and wrong. It may seem obvious that the abolition of public punishment was one of the triumphs of the great age of enlightened reform in criminal law, a century and a half or two centuries ago. ${ }^{12}$ Certainly, it is easy to find books and articles whose authors think that there are fairly clear, and fairly damning, objections to the use of shame sanctions. Some commentators, for example, argue that shame sanctions are inordinately cruel to the offender; ${ }^{13}$ others, that in a modern society such sanctions cannot possibly have any effect at all."

Nevertheless, courts are ordering shame sanctions. And, despite expressions of discomfort, the American legal community seems unable to see any decisive objection to them. ${ }^{15}$ At least one American scholar, Dan Kahan, has in fact cheerfully endorsed shame sanctions. ${ }^{16}$ Another legal scholar, Toni Massaro, has attacked them, ${ }^{17}$ but even she has conceded that such sanctions

12. See infra note 67 and accompanying text.

13. See, e.g., Toni M. Massaro, Shame, Culture and American Crumunal Law. 89 MIICU L. REv 1880. 1942-43 (1991); see also infra Part II (discussing the argument that shame sanctions are cruel to the offender).

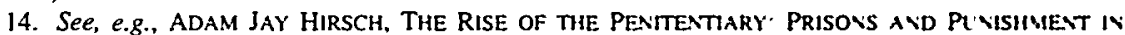
EARLY AMERICA 38 (1992) (arguing that the pillory was no longer effective as a shame sanction "when performed before persons with whom offenders were unacquainted. and with whom they need have no further personal contact"); see also infra Par I (discussing the argument that shame sanctions are ineffective in modem society).

15. Paulv. Davis, 424 U.S. 693 (1976), is an imposing bamer to any constitutional challenge to shame sanctions. Paul involved the circulation by police officials of the names and photographs of persons arrested for shoplifting. The Court held that reputation alone, apart from some more tangible interest such as employment, does not implicate any liberty or propeny interests sufficient to invoke the procedural protections of the Due Process Clause. See id. at 712. While some challenges to preconviction shaming of the kind involved in Paul might conceivably still be mounted. of Persons, supra note 10. at 1557.61 (proposing a Sixth Amendment challenge to preconviction shame sanctions). the faet remans that most of the shame sanctions discussed in this Essay take the form of post-conviction probation conditions Here again, commentators have tried to raise doubts, sec. e.g.. Jon A. Bnlltant. Note. The Modern Da, Scarlet Letter: A Critical Analysis of Modern Probation Conditons, 1989 DU KE L.J. 1357 (arguing that the judictal imposition of shame as a probation condition is a usurpauon of the legislative function), and cours have occasionally stepped in, see, e.g., People v. Meyer. 680 N E.2d 315 (Ill. 1997) (holding that a court exceeded its sentencing authority by imposing a shame sanction). Nevertheless, most courts that have considered the issue have validated shame sanctions. See. e.g. People 1. McDowell. $130 \mathrm{Cal}$ Rptr 839 (Cal. Ct. App. 1976); Lindsay v. State, 606 So. $2 d 652$ (Fla. Dist. Ct. App. 1992); Goldschmutt r State, 490 So. 2d 123 (Fla. Dist. Ct. App. 1986); Ballenger v. State. 436 S.E.2d 793 (Ga. Ct. App. 1993). People v. Letterlough, 613 N.Y.S.2d 687 (N.Y. App. Div. 1994): cf. State v. Bateman. 771 P.2d 314 (Or Cl. App. 1978) (affirming a shaming sentence on procedural grounds): Jeffrey C. Filcik. Signs of the Times Scarlet Letter Probation Conditions, 37 WASH. U. J. URB. \& CoNTEMP. L. 291. 308-18 (1991) (reviewing judicial scrutiny of probation conditions); Rosalind K. Kelley, Comment. Sentenced To Hear the Scarlet Letter: Judicial Innovations in Sentencing-Are They Constutuonal?. 93 DICK. L. REV 759 (1989) (discussing the use of shame sanctions and endorsing humulsating punishments in certaun insiances as a less restricuve alternative to imprisonment). (1996).

16. See Dan M. Kahan, What Do Alsername Sancions Mean', 63 U. CHI L REV 591. 630-53

17. See Massaro, supra note 13, at 1917-44. 
can be justified on the basis of any of the traditional theories of punishment. ${ }^{18}$ Nor has the inability to find objections to shame sanctions been confined to the legal community. The editorial page of the New York Times itself has now declared shame sanctions worth trying, at least under certain circumstances. ${ }^{19}$ Obvious though it may seem that shame sanctions are objectionable, it is unexpectedly difficult to give a name to what troubles us.

My plan in this brief Essay is to acknowledge this unpleasant truth-and then to try, nevertheless, to give a name to what troubles us (or should trouble us) about shame sanctions. ${ }^{20}$ There is simply no straightforward liberal tradition, I argue, that shows why engaging in the mere public display of offenders, without corporal violence, is wrong. In particular, we can canvass all of the great liberal arguments dating to the heroic era when the old shame sanctions were principally abolished, from roughly 1750 to 1850 , but we will find oddly little that is ultimately of use. The classic reformers opposed the old shame sanctions, by and large, for reasons that have almost no relevance to our own age. Shame sanctions were abolished for reasons that have little to do with contemporary American liberal theories.

Still, with some effort, we can see what is wrong with inflicting shame sanctions. Doing so will require us, however, to reject some important and appealing arguments. In the first place, it will require us to reject the argument that shame sanctions can never work in a modern, anonymous society. Contrary to this much-repeated argument, there is good reason to believe that shame sanctions can work in the contexts in which they are most commonly used-for sexual, commercial, and certain other offenses. Second, we will have to retreat from the appealing position that shame sanctions are wrong because of the way they treat the offender-that they are in some way inordinately cruel. As Professor Kahan pointedly observes, it is hard to maintain that shame sanctions, especially ones that do not involve corporal violence, are more cruel than prison; and hard, in any case, to define in a persuasive way what is "cruel" about them." There are ways in which we can think of shame sanctions as "cruel," but these turn out to be unexpectedly complicated. ${ }^{22}$

In point of fact, I contend, the most compelling arguments against pure humiliation sanctions-sanctions that involve only public exposure and not corporal violence-do not have to do either with their ineffectuality or with

18. See id. at 1890-900 (concluding that shame sanctions can be justified on the basis of detcrrence. rehabilitation, retributivism, or incapacitation).

19. See Alternative Sentencing, N.Y. TIMES, Jan. 20, 1997, at Al6.

20. It bears emphasizing that my argument is largely one about intuitions, about our sense that there is something wrong with shame sanctions. This carries with it the obvious danger that some readers will never accept my account. This is not a danger that can be avoided. If our criminal law is, to any extent, to be founded on a shared sense of what is right and what is wrong, then it must involve some coaxing and preaching, and we must accept the truth that not all citizens will agree.

21. See Kahan, supra note 16 , at 646 .

22. As to those who have no sense that there is anything troubling about shame sanctions, 1 hope that my efforts will have some effect on their sense as well. 
their cruelty. The most compelling arguments against such humiliation sanctions do not, in fact, involve the way they deal with the offender at all. As I try to show, the most compelling arguments against shame sanctions involve the way they deal with the public, with society at large, with the crowd. In the last analysis, we should think of shame sanctions as wrong because they involve a species of lynch justice, and a peculiarly disturbing species of lynch justice at that-a species of official lynch justice. The chief evil in public humiliation sanctions is that they involve an ugly, and politically dangerous, complicity between the state and the crowd. Shame sanctions are wrong in our society for the same reason that we feel they are wrong in China, or in the Afghanistan of the Taliban: They represent an unacceptable style of governance through their play on public psychology. This evil is one that we will never fully appreciate so long as we continue to focus exclusively on the effects of shame sanctions on the offender. In fact, it is of no ultimate importance whether shame sanctions are cruel or not. Shame sanctions would be wrong even if they had no impact on the offender at all; for, no matter what, they would represent an improper partnership between the state and the crowd. Even if shame sanctions were wholly unobjectionable from the point of view of punishment theory, they would still fail the test of a sane political theory.

Such is my claim. I proceed by considering and rejecting a variety of arguments against the infliction of shame sanctions. I divide these arguments, in a rough way, into social arguments and political arguments. By social arguments, I mean those that focus on how shame sanctions work within the structure of a given society. One such argument is that shame sanctions do not work at all in a modern society. I consider this contention in Part I. Two classic reformist arguments should also be classified as social: first, that shame sanctions are wrong because they promote the spirit of social hierarchy; and second, that shame sanctions are wrong because they promote a spirit of public indecency and brutality. These two classic arguments are my topic in Part II. In Part III, I turn briefly to a different sort of social argument: the Christian argument that a good society is better disciplined through privately experienced guilt than through publicly experienced shame. After considering all of these social arguments, I turn in Part IV to two political arguments, one classically liberal argument and one classically statist argument. The liberal argument holds that, while shame sanctions can be effective, the state has no business inflicting them; only private citizens may use the sort of "moral" coercion exerted through shaming. The statist argument holds that it is permissible, but unwise, for the state to inflict shame sanctions, for public shaming can have the dangerous consequence of stirring up riots and other mob actions. Neither argument, I conclude, has any direct bearing on our current situation. Of the two, however, the statist political argument is the one that carries the soundest 
kernel of truth. It is really the old statist fear of public riots that tells us the most about the dangers of modern shaming.

Reviewing all of this will involve discussing a great deal of history, from the eighteenth century through the Nazi period. For that very reason, I would like to emphasize one point before beginning in earnest: This Essay is not intended to be $a$ history of anything it discusses. My goal is not to provide a complete account of the rise and fall of western shame sanctions, nor even a complete account of any one episode in this history. My (very different) goal is to dredge the old literature for arguments that might be useful today-to learn, as it were, from the experiences of the dead. This is not the way professional history is usually written; maybe it is not the way history ordinarily should be written. But history can surely be written this way sometimes, and it seems peculiarly appropriate to write it this way here. We are all sharply conscious that the reappearance of shame sanctions is the reappearance of something very old, something for the understanding of which living memory fails us. Perhaps, most of the time, there is not much point in hunting for the wisdom of the past. In this case, however, we feel our lack of living wisdom with peculiar acuteness.

\section{MODERN SHAMing}

It is important to begin by defining the topic with some care. We can sort punishments into roughly five sorts of deprivations: deprivations of life (execution); of liberty (imprisonment); of bodily safety and integrity (corporal violence); of property (fines); and of what we might call "dignity" (shaming). These classifications obviously overlap. In particular, every punishment can involve some element of shaming. It may shame offenders, for example, to send them to prison. Nevertheless, some punishments are more intended to inflict shame than others. Many such punishments involve corporal violence. Flogging, for example, has been regarded in many human societies as an acutely shameful punishment. Branding, too-particularly branding in the face-is a sanction that has carried intense shame in many societies. ${ }^{23}$ Mutilation sanctions, such as slitting the ear or nose, are also sanctions of corporal violence with a heavy element of shaming. In addition, many societies inflict posthumous shame, by mutilating or otherwise maltreating an offender's corpse. $^{24}$

23. See, e.g., Yuvoon Chen, Probleme der Strafe deR Brandmarkung iM Lichte voN RECHTSVERGLEICHENDEN QUELLEN (1948); RUTH MELlinkOFF, THE MARK OF CAIN (1981); Adalbert Erler, Brandmarken ins Antlitz, in RECHTSGESCHICHTE, RECHTSSPRACHE, RECHTSARCHÄOLOGIE, RECHTLICHE VOLKSKUNDE 115 (Ferdinand Elsener \& W.H. Ruoff eds., 1965).

24. See, e.g., AlbERT ESSER, DIE EHRENSTRAFE 67 (1956); Stephen Robert Wilf, Anaromy and Punishment in Late Eighteenth-Century New York, 22 J. SOC. HIST. 507, 515-16 (1989) (discussing punitive dissection as a shame sanction in late 18 th-century America). Shaming can have other posthumous effects, too. In many societies, shameful deaths shame the offender's surviving family. See infra note 127. 
Nevertheless, it is not the case that all shame sanctions involve corporal violence. In particular, some entail purer forms of humiliation. These sorts of sanctions run a wide gamut. They include well-remembered seventeenth- and eighteenth-century practices like the pillory and the stocks. They also include less colorful sanctions, like "exposition," the nineteenth-century French practice of standing a convicted offender before a crowd for an hour;" public forced labor that is intended to attract attention to convicts; ${ }^{26}$ and admonitions and forced public apologies. ${ }^{27}$ It is these sorts of pure shame sanctions, which we could also call "humiliation sanctions," that are reappearing, in new and occasionally inventive forms, in American practice today. (American law also displays a practice akin to humiliation sanctions in the form of laws like New Jersey's "Megan's Law," 28 which requires public notification of the presence in a community of certain released sex offenders. These are not pure humiliation sanctions, though, and I will touch on them only glancingly. ${ }^{29}$ ) These pure humiliation sanctions present a much tougher analytic problem than do shame sanctions involving corporal violence. It is far easier to explain the historical decline of shame sanctions involving corporal violence than it is to explain the historical decline of sanctions involving pure public humiliation. ${ }^{\text {to }}$ It is also far easier to say what is philosophically objectionable about sanctions involving corporal violence than it is to say what is objectionable about pure public humiliation.

Pure humiliation in fact poses a difficult policy puzzle. What is wrong with chaining an offender to a pole in a public square for a few hours, if that offender is not otherwise subjected to violence? What is wrong with making an offender stand, or sit, outside the public courthouse, wearing a sign describing his offense? What, in the least disconcerting case, is wrong with publicizing the names of prostitutes' johns? And how, if at all, can we distinguish these sorts of pure humiliation from other punishments that include some element of shame? How can we say that pure humiliation sanctions are wrong while still maintaining that imprisonment, which also shames to some extent, is not wrong?

Many promoters of shame sanctions over the centuries have defended pure humiliation sanctions. ${ }^{31}$ The latest in this line of commentary is Professor

25. See Code Pénal Progressif: Commentaire sur la Lol Modificative di Cod: PÉn al $124-30$ (Adolphe Chauveau ed., Paris, Bureau de la Jurisprudence Cnmmelle 1832) (heremafter CODE PE.,AL. PROGRESSIF].

26. See infra notes $78-80$ (citing 18th-century thinkers who made such proposals)

27. For a typology of shame sanctions, see Kahan. supra note 16 , at $631-34$

28. Registration and Community Notification Law's. N.J. STAT AvN. $\$ \$ 2 C 7.1$ to -11 (West 1995 \& Supp. 1997).

29. See infra text accompanying notes 140-141, 150-151

30. Indeed, the historians who have made the most important efforts to explan the decline of shame sanctions-historians such as Michel Foucault and Pieter Spierenburg-have noticeably focused on corporal violence. See infra notes 84-86 and accompanyıng text.

31. See, e.g., John Braithiwatte. Crimie. Shame avd Ristegratiov (1989), Juhn Brouhwalte \& 
Kahan's unusually cogent essay. ${ }^{32}$ According to Kahan, there is nothing wrong with pure humiliation sanctions-or at least nothing that is not equalled or outweighed by the horrors and inconveniences of imprisonment. Indeed, given the choice, he points out, offenders prefer shame to prison. ${ }^{33}$ What is more, Kahan argues, shame sanctions probably do as good a job as imprisonment at achieving most of the standard goals of punishment. ${ }^{3.4}$ Here Kahan is joined by Toni Massaro, who, though a critic of shaming, concedes that shame sanctions are fully compatible with standard punishment theory. ${ }^{35}$ There is, these scholars observe, no empirical reason to suppose that shame sanctions cannot deter; they seem beautifully retributive; they may well rehabilitate better than prison does; and they might even serve to incapacitate ${ }^{36}$ Most importantly, given the generally acknowledged failure of imprisonment, Kahan argues, shame should be our alternative sanction of choice; ${ }^{37}$ unlike all other alternatives, shame sanctions do a particularly fine job of satisfying our "expressive" needs, dramatizing society's condemnation of the offense in a gratifying way. ${ }^{38}$

How should we respond to such a defense of public humiliation?

In part, we might say that Professor Kahan's particular argument, with its serene embrace of an "expressive" theory, is a bit surreal in this context. Speaking of shame sanctions as "condemnation" does not do justice to our intuitive sense of their peculiar kind of brutality and terror. ${ }^{39}$ But, even leaving the expressive theory aside, defenses of shame sanctions give the impression of somehow being strangely unacquainted with the traditions of liberalism. Surely, one thinks, there must be something in the writings of

Stephen Mugford, Conditions of Successful Reintegration Ceremonies, 34 BRIT, J. CRIMINoLoGY 139 (1994); sources cited infra note 80.

32. Kahan, supra note 16.

33. See id. at 641 n.204, 646.

34. See $i d$. at $638-41$ (discussing deterrence); id. at $644-46$ (discussing reintegration); id. at 649 (discussing retribution).

35. See Massaro, supra note 13, at 1890-900.

36. See id. (arguing that shame sanctions are justifiable on all standard theories of punishment).

37. See Kahan, supra note 16 , at 653 .

38. Id.

39. Even accepting the propriety of using expressive punishment theory, it is important to recognize that Professor Kahan has not really taken the full measure of the liberal expressive tradition. Kahan allows himself to write as though imprisonment were intended to express simply the wrongness of the offense. Yet the liberal tradition has always claimed something grander. The classic claim of the liberal tradition is not simply that imprisonment expresses the "wrongness" of the offender's offense in positive law. Imprisonment, in the classical liberal account, "expressively" reaffirms the value of liberty, a prevailing social value different from anything expressed in positive law. See id. at 613. Professor Kahan knows this liberal tradition, but I do not think he has taken the full measure of what it implies. The early 19th-century liberal tradition always took the view that punishment does more than reaffirm, in a good thumping bloody way, the illegality of what society regards as illegal. The liberal tradition always held that the system of punishment functions, not by reaffirming that the offender has done wrong, but by excluding the offender from participation in some larger social good. The problem with shame sanctions as alternative sanctions, on this classical liberal line of argument, seems clear enough: Shame sanctions affirm the wrong underlying social values. 
Immanuel Kant, or of John Stuart Mill, or of someone in the great liberal tradition, that reveals why shame sanctions are wrong.

Well, there are classical liberal propositions that militate against the use of shame sanctions. But the truth that I would like to begin facing in this Essay is that those classical propositions bear little weight. Running down the classical liberal attacks on shame sanctions turns out to be a disappointing business.

Historically, the most powerful liberal argument against shame sanctions, the one most extensively discussed in American legal literature, is the argument from modernity, as it were: the argument that, in a modern, anonymous, urban society, shame sanctions cannot possibly work. The argument from modernity is a proposition with some old roots, running well back into the eighteenth century. ${ }^{40}$ In its very widespread modern form, it has assumed a place at the heart of sociological realism in the liberal tradition; indeed, any number of sociologically informed commentators have embraced it. $^{41}$ The most recent advocate of the argument from modernity is Professor Massaro, whose carefully argued 1991 article presents it in forceful fashion. ${ }^{42}$ As these commentators point out, the face-to-face interaction that used to be the stuff of village society (and that, in some sense, is perhaps still the stuff of Japanese society) has collapsed in the modern, western world. Yet without such face-to-face interaction, the argument runs, shame sanctions cannot work. This follows from the very nature of shame itself, for shame is an emotion that we feel in the presence of others who know us and know our misdeeds. Shame is the loss of face in the eyes of neighbors who have the village habit of condemning any kind of deviance and from whom one cannot escape. Yet the essence of the anonymity of modern western city life is that one can always escape. There is no point in shaming offenders who can instantly slip into the back streets and who are likely, in any case, to move in an underworld population that is very far from condemning the deviant. Indeed, at its worst, shaming such characters may simply force them to renounce law-abiding society entirely, moving into the underworld for good. ${ }^{43}$

40. See, e.g., Matthias CaLonius, Dissenaho Juridica de Delinguentum ad Publicam lgnominum Expositione, in 2 Matthiae Calonil OPERA OMNia 237. 237.38 (A I Aru idsson ed . P A Norstedi \& Filı 1830) (1788).

41. See, e.g., HIRSCH, supra note 14. al 32-46

42. See Massaro, supra note 13.

43. See id. passim; Persons, supra note 10, at 1538-40; of JOSEPH EDOLARD BOTARD. LECOUS SLR Les Codes PÉNal et D'INSTRuction Criminelle 52-53. 56-57 (Pans. Libraine de Junsprudence de Cotillon 1851) (presenting a similar argument with respect to mu-19th-century France). Bramiwarte. supra note 31, at 59-60 (presenting a similar argument with respect to Contunental Europe dunng the Middle Ages); [F.-M. VeRMEIL], ESSAI SUR LES REFORMES A FAIRE DA IS NOTRE LEGISLATIO \ CRIMINELLE 14 (Paris, Demonville 1781) (presenting a similar argument with respect to pre-Revolution France) Professor Massaro, in a more recent and as yet unpublished manusenpt. argues that the shect complexity of the phenomenon of shame makes any hope of legal reform based on shame sanctions thin See Ton $M$. Massaro, The Meanings of Shame: Implications for Legal Reform 88 (1997) (unpublished manuscript, on file with the Yale Law Journal). 
Why doesn't this venerable argument resolve the question? It is founded in some deep and well-established sociological arguments, and it has the great merit of making apparent sense of a divide between western and nonwestern legal cultures. The argument may seem at first glance to be our best route to preserving an enlightened and informed liberalism.

Nevertheless, the argument from modernity, powerful though it may seem, fails for a variety of reasons. In part, it fails for a reason to which I will return: If our most pressing concern is the impact of shame sanctions on the public, rather than their impact on the offender, then it is of no great consequence to say that they fail to provoke shame in offenders ${ }^{44}$ But, even leaving that point aside, the argument from modernity is weaker than it seems for two reasons. First, shame sanctions are in practice inflicted only on certain, peculiarly vulnerable classes of offenders; and second, the psychology of shame is arguably something different, and more complex, than the argument from modernity supposes.

Let us begin with the particular classes of offenders upon whom shame sanctions are visited in America. Though the point is often little discussed in the literature, the fact is that shame sanctions are not now used (and have never been used) for every type of offense. ${ }^{45}$ On the contrary, shame sanctions are typically applied to a fairly strictly delimited range of cases. Broadly speaking, we can identify three classes of offenses typically penalized through shame sanctions: (1) sexual and morals offenses; (2) commercial offenses; and (3) first and minor offenses. It is not at all difficult to see why shame sanctions have real impact in these three limited spheres. ${ }^{46}$

Beginning with sexual and morals offenses, it should come as no surprise if persons charged with sexual offenses are psychologically vulnerable to shame sanctions-no surprise, though not something that is entirely easy to analyze either. We can all sense that someone charged with, for example, patronizing prostitutes is likely to dread public exposure. The same is likely true of someone charged with child molestation-though his is a psychology of which we have a difficult time developing any kind of intuitive grasp. Offenders of these kinds belong to a very old class of persons subject to shame sanctions-persons such as adulterers (and conversely cuckolds), who were historically among the most common targets of shame sanctions. ${ }^{47}$ They

44. See infra Part V.

45. See Michael. Ignatieff, A Just MEasure of Pain 21 (1978) (discussing the use of shame sanctions against homosexuals and shopkeepers). For an argument that the fine, rather than shaming, was the predominant sanction in colonial New York, see JULIUS GOEBEL, JR. \& T. RAYMOND NAUUGHTON, LAW ENFORCEMENT IN COLONIAL NEW YORK 709-10 (1944). See generally FRIEDMAN, supra note 7, at 38 (discussing the use of shame sanctions in colonial law).

46. The limited range of offenses for which shame sanctions can be used was implicitly acknowledged by the New York Times in its editorial endorsing the use of such sanctions. See Alternative Sentencing. supra note 19. It is odd that journalists should notice what scholars seem slow to see.

47. See the treatments of the famous humiliation right called the "charivar?" in HENRI REY-FLAUD, Le Charivari: les Rituels fondamentauX DE LA SeXualite (1985); and Le Charivari (Jacques Le 
belong to the class of sex offenders, and there is nothing that should surprise us in the fact that this class is vulnerable to shame sanctions, once we acknowledge that shame includes a sexual component. Exactly what that sexual component might be is a matter of dispute among psychologists and philosophers. ${ }^{48}$ (This is a tough question to which I will return.) ${ }^{49}$ But whatever our ultimate analysis of the sex-shame nexus may be, it is indisputable that offenders will often be peculiarly susceptible to shaming when they are charged with a sexual (or, perhaps more broadly, a "morals") offense. Shame, particularly in a Christian or post-Christian society, always shadows us in our sexual activities. Even solitary sexual activity can be accompanied by shame..$^{50}$ There is, therefore, no reason to think that sexual offenders will feel shame only when confronted by familiar neighborly faces. On the contrary, there is much reason to think such offenders will suffer a hard psychic blow regardless of the social setting in which they are exposed. The fact that one's sexual activities have been exposed has a way of lodging itself inescapably in one's consciousness.

Indeed, the case of the sexual offender begins to reveal to us a truth to which I will return repeatedly, a truth that tends to undermine the argument from modernity: namely that it is wrong to think of shame solely as public shame, solely as an emotion triggered by the gaze of others. Shame, as recent

Goff \& Jean-Claude Schmilt eds., 1981). The charwarı was a common ntual of mochen, often desending into violence, most frequently (but not exclusively) directed at older women who marned younger men The varieties of the charivari as "ritual[s] of popular justuce" are also discussed in PETER BL RKE. POpL LAR CULTURE IN EARLY MODERN EUROPE 198-99 (Harper \& Row 1978) (1978): IGNATIEFF, supru note 45, at 40; and sources cited in id.

48. For a discussion of the sexual conient of shame in the Freudian tradition, see GERHART PIERS \& Milton B. Singer, SHAME AND Guilt 18-19 (1971): for an effor to distunguish shame from "sexual guilt," see $i d$. at 22-23; for a discussion of the relatuve neglect of shame in that tradition. see ERIK $H$ ERIKSON, CHILDHOOD AND SOCIETY 252 (2d ed. 1963); and for a suncy of the neglecl generally. see Gershen Kaufman, The Psychology of Shame 3-4. 7-11 (Rouiledge 1993) (1989) for an effon to distinguish inferiority shame from sexual shame. so J. GoLDBERG. LA CLLPABILTE AXIOME DE LA PSYCHANALYSE (1985). For an argument that sexual exeitement is associated with the expenence of shame. see Marco Walter Battacchi \& Olga Codispoti. La Vergogna. Saggio di Psicologia Divasica E CLINICA 27-28 (1992); and sources cited in id. See also Donald L. Nathanson, A Timefuble for Shame. in MaNy FaCes of Shame 1, 39-45 (Donald L. Nathanson ed., 1987) (discussing evidence linking the development of shame with that of genitality). Freud claimed that the exposure of the genitals uas the root of shame. See SIGMUND FREUd, CIVILIZATION AND ITS DISCONTENTS (1930), reprinied in 21 THE STANDARd EDITION OF THE COMPLETE PSYChOLOGICAL WORKS OF SigMi'No Freld $57,99 \mathrm{n} I$ (James Strachey et al. trans., 1961). For a more recent treatment growing out of the psychounal, tic tradition. sec LÉON WURMSER, THE MASK OF ShaMe 174.93 (1981).

As the survey in Kaufman's work suggests. the weight of the arguments of psychologists may Hell be against any emphasis on sex. See KAUFMAN, supra, at 7-11 (treating sexual sources of shame as only one type among many). For a recent effort al explanation placing little or no weight on sex. sec RICHARD S. LAZARUS, EMOTION AND ADAPTATION 243-44 (1991). I take 1t, however, that eicn psychologisls who see no deep sexual content in shame would not deny that much of the expenence of shame involies sexual thoughts and activities. For philosophically oriented treatments laying more weight on ser and. more broadly, on bodily functions, see MAX SCHELER, Ober Scham und Schamgefuhl, in I SCIRIFTES ALS DEM NACHLASS 65, 69-77 (Maria Scheler ed., 1954), which discusses bodily shame, and CARL. D SCHVEIDER. SHAME, EXPOSURE AND PRIVACY (1977).

49. See infra notes 108-115 and accompanying text.

50. This point is emphasized in SCHELER, supra note 48 . at 78 
philosophical and psychological commentators have insisted, can also be triggered by the sound of an inner voice or the gaze of an inner eye. ${ }^{51}$ Even when alone, we are capable of feeling that our sense of self has been permanently damaged because we were exposed somewhere, sometime. This is perhaps peculiarly true of sexual shame, for we are quite capable of feeling sexual shame without ever being witnessed; but, as Bernard Williams has argued, the same is also true of other sorts of shame. ${ }^{52}$ The argument from modernity rests on a questionable notion of shame, one that reduces it too casually to an emotion experienced only when we are under the direct gaze of others.

If the argument from modernity seems to carry little weight in the realm of sexual offenses, the case is no different with respect to the other spheres in which shame sanctions are typically applied: the spheres of commercial and of minor or first offenses. With respect to the first of these, shame sanctions have a long history of being applied to commercial offenders. For example, in the medieval and early-modern world, a range of garish and brutal forms of public pillorization was visited upon bankrupts, who were often required to bang their bare buttocks against rocks in public. ${ }^{53}$ Similar treatment was administered to other sorts of commercial offenders. ${ }^{54}$ Nor is commercial shaming limited to premodern history (or to contemporary China). America uses it too. As the New York Times is certainly right to point out, one of the watershed developments in the reemergence of shame in the United States involved the sphere of commerce: Then-U.S. Attorney Rudolph Giuliani's decision to make humiliating public arrests of Wall Street brokers marked a leap toward a new use of prosecutorial power. ${ }^{55}$

Should we expect such commercial shaming to work? We should indeed, partly for a reason that suggests itself immediately: Merchants and participants in the world of business inevitably fear loss of reputation, for a variety of legal and sociological reasons, and with particular intensity. For practical purposes,

51. See, e.g., June Price Tangney et al., Are Shame, Guilt, and Embarrassment Distinct Emotions?, 70 J. PERSONALITY \& SOC. PSYCHOL. 1256, 1256 (1996) ("Contrary to popular belief, shame [is] no more likely than guilt to be experienced in 'public' situations; ... [both] emotions typically occurred in social contexts, but a significant proportion of shame and guilt events occurred when respondents were alonc.").

52. See Bernard Williams, Shame and Necessity 82 (1993).

53. See James Q. Whitman, The Moral Menace of Roman Law and the Making of Commerce: Some Dutch Evidence, 105 YALE L.J. 1841, $1871-78$ (1996).

54. See, e.g., IGNATIEFF, supra note 45 , at 21 (describing the treatment of shopkeepers); $c f$. BURKE, supra note 47, at 160-61 (describing popular hostility toward businessmen in early-modern Europe). Something of the same spirit can perhaps be seen in sentences that seek to "shame" corporations. See Andrew Cowan, Note, Scarlet Letters for Corporations? Ptinishment by Publicity Under the New Sentencing Guidelines, 65 S. CAL. L. REV. 2387 (1992). Corporations, of course, cannot experience the emotion of shame; shame sanctions directed against them would nevertheless be objectionable on the criteria I articulate below. See infra Part V.

55. See Jan Hoffman, Crime and Punishment: Shame Gains Popularity, N.Y. TIMES, Jan. 16, 1997, at Al; cf. Scot J. Paltrow, The Drexel Agreement To Settle; The Prosecufor; Giuliani Has Fans, Foes in War on White-Collar Crime, L.A. TIMES, Dec. 22, 1988, $\$ 4$, at I (discussing the mixed response to Giuliani's tactics). 
the world of commerce is not an anonymous world. ${ }^{56}$ This is a point known well enough, and made often enough, in the literature of commercial law ${ }^{57}$ that it should not need a lot of emphasis. But shamed merchants are likely to suffer harms from shame sanctions that go beyond the conventional loss of commercial reputation. It may be that merchants value their reputations not only for reasons of economic self-interest, but also because they have an attachment to a kind of bourgeois respectability that shame sanctions peculiarly threaten. This is undoubtedly not as true today as it was in the nineteenth century, or even in the 1930s or 1950s, but it is obviously still true to some extent. Public humiliation is, surely, still especially painful for many "respectable" businessfolk. ${ }^{58}$ There is thus plenty of reason to believe that commercial shaming can be effective.

What, then, about the category of first and minor offenders? These may well be persons whose offenses have no taint of sex and whose sensibilities are thoroughly unbourgeois. Can we safely assume that shame sanctions would have no impact on these offenders? I do not think we can assume any such thing - though the reasons here have less to do with the psychology of shame than with the anthropology of status in our society. I suggest that we make, sometimes consciously, sometimes not, a sharp status distinction between respectable and criminal segments of the population. First and minor offenders-persons such as shoplifters or drunk drivers-are persons whom we regard as unable to grasp this sharp distinction, as unable to sense how disreputable it is to engage in crime $;{ }^{59}$ they are persons whom we regard as somehow not "really" belonging to the status group of criminals, even though they have engaged in criminal behavior. When officials inflict a shame sanction on a person in this category-circulating a shoplifter's photograph after his detention, ${ }^{60}$ for example, or requiring a drunk driver to wear a pink bracelet reading "D.U.I. CONVICT" edging toward true disreputability. We may think of shame sanctions in this context as liminal rites, rites that warn first and minor offenders that they are

56. See, e.g., Robert C. Post, The Social Foundations of Defamation Luw. Repuration and the Constitution, 74 CAL. L. REv. 691, 693-95 (1986) (describing the value of reputation for individuals who engage in marketplace relations).

57. See David Chamy. Nonlegal Sancions in Commertal Relationships. I0-4 HARV L REV 375. 393 \& n.64 (1990); see also Seth F. Kreimer. Sunight. Secrefs, and Scarlel Lelters- The Tenston Bemeen Privacy and Disclosure in Consitutional Law, 140 U. PA. L. REV I. $51-54$ (1991) (describing the social stigma created by government disclosures).

58. Cf. Kahan, supra note 16, at 643 (descnbing potential disgrace as part of the calculus of an executive considering illegal behavior). I would also note that deeper mystenes may lic here. 100 At least in European history, commercial shame and sexual shame have had a long. deep. and puzzling connection. one that arguably goes back all the way to Paul's first Epistle to the Thessalonians, which seemed to many readers to equate commercial and sexual sinning. See Whtman. supro note 53 . at 1859 \& $n 62$ idiscussing I Thess. 4:3-8).

59. Drunk drivers are very common targets of modern Amencan shame sanctions See Massaro, supra note 13 , at 1886-87.

60. See Paul v. Davis, 424 U.S. 693,695 (1976).

61. See Ballenger v. State, 436 S.E.2d 793. 794 (Ga. Cl App 1993) 
flirting with a deep, and deeply undesirable, status change. There is good reason to expect that such shame sanctions will have a real psychic impact, for rites of this kind are powerful things. ${ }^{62}$ Though our sense of status may be dark and inarticulate, it is psychologically strong. Warning people that they are brushing up against outcast status is therefore likely to have an impact on at least some of them. ${ }^{63}$

There is no point in exaggerating the power of these observations. It is undoubtedly the case that some sex offenders, some merchants, some shoplifters, and some drunk drivers will laugh off attempts at public humiliation. ${ }^{64}$ But it is implausible to think that all, or even most, of them will. Once we reflect on what shame is, and when shame sanctions are applied, the argument from modernity seems a slim thread from which to hang our opposition to shame sanctions. Shame sanctions are likely to work in the ways in which they are applied, even in a modern, western, urban society, for they are, in practice, only inflicted in certain dark corners of our social world. That shame sanctions should work is no more than what we might expect from the simple fact that courts impose them. Courts do so because they think, with good reason, that shame sanctions will have a real effect.

\section{FORMS OF SOCIAL INDIGNITY}

We must begin our reasoning, then, from the assumption that shame sanctions, as applied, are in fact likely to work. We must also narrow our inquiry somewhat. The question is not, "What is wrong with shame sanctions as such?" The real question is, "What is wrong with shame sanctions as we apply them?" If a government engages in shaming in a few, shadowy corners of social life, what is it doing that is improper?

Our first intuitive response may be to say that any such government is violating a venerable liberal prohibition on cruelty. This is something we might say even while recognizing that modern American shame sanctions do not involve corporal violence. The cruelty of shame sanctions, it might be said, . involves something other than inflicting physical pain on offenders. In particular, we might argue that regardless of how scrupulously shame sanctions leave the body of the offender intact, they violate the offender's dignity in

62. See ARnold van Gennep, The Rites of Passage 39-40 (Monika B. Vizedom \& Gabrielle L. Caffee trans., University of Chicago Press 1960) (1908) (describing rites of separation from, and integration into, groups).

63. Shame sanctions in this context can also be thought of, incidentally, as addressed to socicty at large. By marking first and minor offenders as persons edging close to the borderlands of forbidden conduct, we mark for everyone the dangerous point at which one might cross over from the law-abiding to the criminal class.

64. In addition, it is worth noting that these classes overlap to some extent. Drunk drivers are, of course, also morals offenders of a kind (leaving aside the hard question of how "morals" offenses relate to sexual ones). Shoplifting is, of course, also a violation of commercial morality. 
some objectionable way-that they run contrary to some deep norm requiring us to treat even criminals with respect. The government, we would say, properly has the power to deprive offenders only of property or liberty, but never of dignity.

This argument certainly has a kind of intuitive rightness to it. But it is obviously inadequate as an account of what is wrong with shame sanctions, unless and until it is fortified by some account of what "dignity" is. ${ }^{6 s}$ Toward the end of this Essay I try to develop a concept of "dignity" that may suit our needs, ${ }^{66}$ but for the moment I would like to stick with my program of reviewing the legacy of the classical liberal tradition. What is it that violates principles of liberalism in presenting an offender to the eyes of the public? Can we find a concept of "dignity" in the social views of the classical liberal tradition that will satisfy us?

The answer, once again, is disappointing. Here too, the classical liberal tradition leaves us disappointingly devoid of answers, or at least of answers that have any clear relevance to the society in which we live now. To make this point, I would like now to turn to history, to the great era of reformist debate over shame sanctions, the period from roughly 1750 to $1850 .^{67}$ This is the period when our liberal tradition was formed, at least with respect to shame sanctions. It is during this period, we would hope, that persuasive dignitary arguments against shame sanctions might be found.

And when we investigate what we might broadly call the social reformers of this period, we do indeed discover some more or less dignitary arguments. In particular, we can identify two separate reformist campaigns of relevance: a campaign for status revolution, which began, roughly speaking, in the mideighteenth century; and a campaign for moral revolution, which began in the Victorian era, roughly around the second quarter of the nineteenth century. In the first and more easily understood of these, reformers attacked shame sanctions for promoting a spirit of social hierarchy. In the second and much more mysterious campaign, the reformers attacked shame sanctions for promoting public indecency or a surrender to our animal nature.

Let us begin with the first. As reformers from the mid-eighteenth century onward were well aware, early-modern shame sanctions frequently operated by

65. Massaro is a notable example of an author who is inclined to condemn shaming as a violation of dignity but who finds it difficult to specify exactly the sort of "dignity" involved. See Massaro. supra note 13 , at $1942-43$.

66. See infra note 155 and accompanying text.

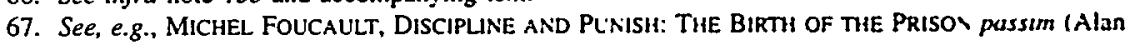
Sheridan trans., Pantheon Books 1977) (1975): IGNaTiefF, supra note 45, passm The roots of modem. occidental opposition to shame sanctions seem to reach well back into the 16 th and 17 th ecntunes. See. e.g., JULIUS ClarUS, ReCEPTARUM SENTENTIARUM OPERA OMNia 335 (Frankfun am Main. Ex Officina Typographica Nicolai Bassaei 1596) (noting the decline of publıe punishment for clencs in late 16th. century Italy); 2 John SElden, DE SYNedRIIS \& Praefectiris Itridicis Veterl' (London, Typis Jacobi Flesher 1653) (objecting to the pracuce of public flogging) Pursuing this carly history, however, is beyond the bounds of this Essay 
symbolically lowering the offender's standing in the established social hierarchy. ${ }^{68}$ This symbolic lowering of status was made possible by the fact that, by very longstanding tradition in the premodern world, different punishments were used for different social status groups. The most famous of these differences pertained, of course, to capital punishment: Members of the nobility were beheaded, while commoners were hanged. ${ }^{69}$ It was accordingly status-degrading to hang a nobleman and status-enhancing to decapitate a commoner. $^{70}$ (It was for this reason that the guillotine was considered a "revolutionary" device-it extended the benefit of decapitation to a large, and formerly deprived, segment of French society.)

But the status distinctions embedded in punishments were by no means limited to forms of capital punishment. Most shame sanctions, for example, were low-status punishments. Subjecting an offender to shame sanctionsparticularly to sanctions such as flogging, but also to mere public exposure-amounted to treating the offender as a member of a low social order. The "dignity" of which shame sanctions robbed the offender was thus, in part, "dignity" in a narrow, technical, premodern sense: The infliction of a shame sanction robbed the offender of any claim to an honored place in an articulated social hierarchy of deference. ${ }^{11}$

It should be clear enough why this status-heavy character of early-modern shame sanctions stirred social reformist zealotry. Shame sanctions belonged to the great baroque structure of social hierarchy that revolutionaries of the later eighteenth century were most eager to dismantle. ${ }^{72}$ The attack on shame sanctions thus partook of the same spirit that led to the introduction of the guillotine and the abolition of sumptuary laws: It was an attack on status distinctions, on the very idea that there should be high-class and low-class punishments. ${ }^{73}$ Liberal thinkers of the turn of the eighteenth century and after, such as Benjamin Rush and Wilhelm von Humboldt, put a subtle theoretical gloss on this campaign. As they argued it, a society's form of punishment should reflect that society's sense of its highest good. ${ }^{74}$ In a society whose

68. See, e.g., Kahan, supra note 16, at 611-12.

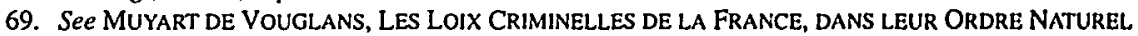
833 (Paris, Morin 1780).

70. See id. (explaining that decapitation does not dishonor an executed person).

71. For an enlightened defense of status distinctions in shame penalties, see VERMEIL, supra note 43. at 115-16. It was this aspect of early-modem shame sanctions that stimulated Gustav Radbruch's famous hypothesis about the historical evolution of criminal law: The evolution of criminal law, he argued, had involved the gradual extension of punishments first used for the lowest orders of societies to higher and higher orders. See GuSTAV RadBrUCH, ElegantiaE JURIS CRIMINALIS 5 (2d ed. 1950).

72. For an attack on shame sanctions in light of this tradition dating to the French Revolution, sec P.C.

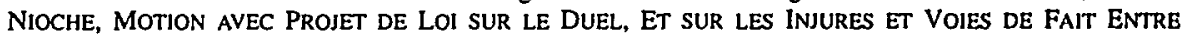
CITOYENS 55-57 (Paris, P. Provost 1791).

73. For a description of this reasoning in the 19th century, see, for example, MYRA C. GLENN. Campaigns against Corporal Punishment: Prisoners, SaIlors, WOMEN and ChILdREN IN ANTEBELLUM AMERICA 111 (1984).

74. See Wilhelm von HumboldT, The Limits of StATE Action 112 (J.W. Burrow ed., Liberty Fund 1993) (1792); BENJAMIN RUSH, AN ENQUIRY INTO THE EFFECTS OF PUBliC PUNISHMENTS UPON 
highest good was liberty, the proper punishment should accordingly be deprivation of liberty. Only in a preliberal society that regarded social status as the highest good should the form of punishment involve deprivation of social status, of dignity.

These were elegant arguments. But, as Professor Kahan is surely right in observing, ${ }^{75}$ these arguments make clear how little bearing the classical liberal situation has upon our own. The fact is that our society no longer possesses nicely articulated status distinctions. We do not have "dignities" of the premodern kind. In particular, our society no longer attaches different status meanings to different punishments; or, at least, if it does, those status meanings do not attach to shame sanctions as such. ${ }^{76}$ This is not to say that the punishments we inflict lack status meaning completely; as I have suggested, shame sanctions may be used precisely for offenders who have not yet sunk fully to criminal status. ${ }^{77}$ But it is no longer the case that when we inflict shame punishments we symbolically depress the offender's standing in a legally defined social hierarchy; we have none of the old sense that a person once subjected to public shaming has become socially untouchable. While we may remain sympathetic to the revolutionary drive toward status equality, we can no longer have any sense of how eliminating shame sanctions might contribute to that drive.

The drive toward status equality, however, was not the only classical liberal impulse toward dignitary social reform. In fact, it was not amidst the drive toward status equality that shame sanctions were ultimately abolished. This point deserves some emphasis since many of us imagine that shame sanctions were eliminated in the course of the eighteenth century. Yet it is by no means the case that every figure of the ages of Enlightenment and Revolution thought that shame sanctions were a bad thing. Cesare Beccaria ${ }^{78}$ and Jeremy Bentham, ${ }^{79}$ most notably, but other Enlightenment figures as

\footnotetext{
CRIMINALS AND UPON SOCIETY 19 (photo. reprint, n.d.) (1787)

75. See Kahan, supra note 16, at 611-16.

76. On the contrary, to the extent that $I$ am nght in my analy sis of shame sanctions as applied to tirst and minor offenders, i.e., persons who have not acquired crmunal status. see supra notes 59.63 and accompanying text, we must say that Amencan shame sanctions are now punishments used typically for upper-status offenders. But of. Carol S. Stetker. Pumshment and Procedure. Punishment Theon and the Criminal-Civil Procedural Divide, 85 GEO. L.J. 775. 797 n. 120 (1997) (altach 1 g Katan on the ground that shaming will have a harsher impact on minonies and other disadiantaged persons). 1 am nol persuaded by Professor Steiker's argument: Shame sanctions seem. if anythıng. to be altematuve sanctions for privileged persons who would otherwise be incarcerated

77. See supra notes $59-63$ and accompanying lext

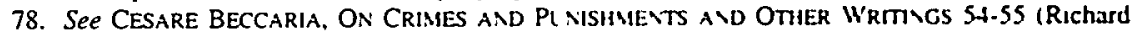
Bellamy ed. \& Richard Davies et al. trans., Cambridge Univ. Press 1995) (1765), see also Eberhard Weis. CESARE BECCARIA (1738-1794). MAILANDER ALFKLARER L ND A \REGER DER STRAFRECITSREFOR MES IV EUROPA 15 (1992) (describing Beccana's argument for publıc forced labor).

79. See JeREMy BeNthAM. THE TheORY OF LeGISLATION 347-50 (C.K. Ogden ed. Fred B Rothman \& Co. 1987) (1931) (proposing a vanety of shame sancions to replace the pillory)
} 
well, ${ }^{80}$ thought of shame sanctions as an indispensable punishment device. Indeed, despite some partial abolitions in the French and American Revolutions, shame sanctions survived into the post-Napoleonic era. ${ }^{81}$

The practice of public humiliation, in fact, was decisively ended only toward the middle of the nineteenth century. ${ }^{82}$ By that time, reformers no longer emphasized status dignity, at least not to the extent that they had in the eighteenth century. ${ }^{83}$ The reformers who succeeded in eliminating shame

80. See, e.g., [WILliam Eden AuckLand], Principles of Penal LaW 57, 59 (London, B. White \& T. Cadell 2d ed. 1771) (opposing branding, mutilation, and other punishments that "fix a lasting, visible stigma upon the offender," but nonetheless supporting "the stamp of ignominy" as the "best instrument for the promotion of morality, and the extirpation of vice"); HENRY FIELDING, AN INQUIRY INTO THE CAUSES OF THE LATE INCREASE OF ROBBERS, \&C. (London, A. Millar 1751) (condemning various aspects of public executions but concluding that they ought to be "solemn" and "in some degree private," with an cye to impressing the imagination of the crowd more vividly), reprinted in 13 HENRY FIELDING, THE COMPLETE WORKS OF HENRY FIELDING 5, 122-25 (Croscup \& Sterling Co. 1902) (1793); INSTRUCTION DONNÉE PAR CATHERINE II IMPÉRATRICE ET LÉGISLATRICE DE TOUTES LES RUSSIES, A LA COMMISSION ÉTABLIE PAR

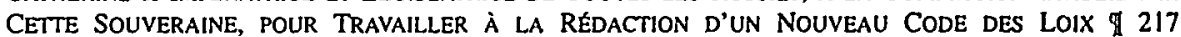
(Lausanne, Chez Francois Grasset \& Co. $2 \mathrm{~d}$ ed. 1769) (ordering the avoidance of sanctions involving corporal violence but the application of shame sanctions with regard to "enthusiasts, those who pretend to some divine inspiration, those who wish to pass for saints" (translation by author)); LACRETELLE, DISCOURS SUR LE PREJUGÉ DES PEINES INFAMANTES 363 (Paris, Chez Cuchet 1784) (stating that the object is to make the use of shame sanctions "more wise, more varied, more frequent" (translation by author)); J.H. DE ROUSSEL DE LA BERARDIËRE, DISSERTATIONS SUR LA COMPOSITION DES LOIX CRIMINELLES 33-34 (Lciden, Heyligert \& Hoogstraten 1775) (praising Beccaria and proposing that convicts be subjected to "the most vile and painful public labor" before the eyes of the community (translation by author)). For the same kind of argument in the early 18th century, see CHRISTIAN THOMASIUS, DE EXISTIMATIONE, FAMA, ET INFAMIA EXTRA REM PUBLICAM (n.p., 1709), reprinted in 3 DISSERTATIONUM ACADEMICARUM VARII INPRIMIS IURIDICI ARGUMENTI 239, 258 (Halle, Impensis Ioannis Iacobi Gebaveri 1777) (hereinafter DISSERTATIONES]. Thomasius asserts the value of shame sanctions but concedes that flogging "ans we practice it today . . . does not seem completely rational." Id. (translation by author); see also CHRISTIAN Thomasius, An PoEnae Viventium, eos Infamantes, Sint Absurdae ET Abrogandae? (Thomasius, Praeses, Johann Heinrich de Kalm, Respondent) (n.p., 1723) [hereinafter THOMASIUS, AN POBNAE VIVENTIUM] (quoting a statute of King George I for Hanover, dated December 28, 1717, which commuted public whipping and the like into a sentence of forced public labor), reprinted in 4 DISSERTATIONES, supra, at $539,576-77(1780)$.

81. To catch the mood of declining revolutionary fervor leading into the 19 th-century practice in France, see [TARGET], PROJET DU CODE CRIMINEL, CORRECTIONEL ET DE POLICE at xviii (n.p., 1802), which explains the necessity of retaining the practice of branding. For vivid early 19th-century descriptions, see, for example, 1 M.B. SAINT-Edme, Dictionnaire dE LA Pénalité dans Toutes les Parties du MONDE CONNU 37-39 (Paris, Plassan 1824), which describes English attainder; 3 id. at $156-60$ (1825), which describes the French carcan; id. at 180-81, which describes the Scottish cavalcade; $i d$. at 338-50, which describes the degradation from rights; and $4 \mathrm{id}$. at $84-87$ (1828), which describes branding.

82. See BoITARD, supra note 43, at 56-57 (describing mid-century French reforms); EsSER, supra notc 24, at 71-72 (explaining that in Germany public humiliation as punishment generally fell out of use in the mid-19th century but that, in certain respects, its use continued into the 1930s); 4 LEON RADZINOWICZ. A HISTORY OF ENGLISH CRIMINAL LAW AND ITS ADMINISTRATION FROM 1750, at 343-53 (1948) (describing public executions in Great Britain); 1 JAMES FITZJAMES STEPHEN, A HISTORY OF THE CRIMINAL LAW OF ENGLAND 489-90 (London, MacMillan 1883) (describing punishments for misdemeanors in Great Britain); PAUL DE WIN, DE KAAKSTRAF IN BELgië VAN DE FRANSE TIJd TOT 1867 passim (1992) (tracing carly 19th-century reforms); see also Simon Coldham. Crime and Punishment in British Colonial Africa, in 4 LA PEINE, supra note 3, at 57,61 (noting the survival of public execution in British colonial Africa into the 1930s).

83. The status-based argument certainly survived in the 19th century, especially in Germany, where it was framed in the typical language of historical analysis of Roman and Germanic law. See, e.g., ThEOdOR MAREZOLL, DAS GEMEINE DEUTSChE CRIMINALRECHT 151-55 (Leipzig, Verlag von Joh. Ambrosius Barth 1847). German traditions of debate, it should be noted, were substantially different from 19th-century western traditions. I do not, however, discuss the German traditions further in this Essay. 
sanctions were not the status revolutionaries of the eighteenth century but the moral revolutionaries of what we may call, extending an Anglo-American term to the larger West, the Victorian era. These successful Victorian-era reformers spoke of "human dignity" in a grander, more vague, and more mysterious way.

The abolition of shame sanctions in the Victorian era presents, in fact, some difficult interpretive problems. Some of the Victorian opposition to shame sanctions clearly grew out of distaste for punishments involving corporal violence. Indeed, historians who have tried to explain the Victorian abolition, like Michel Foucault, ${ }^{84}$ Pieter Spierenburg, ${ }^{85}$ and Myra Glenn, ${ }^{86}$ have focused very heavily on the emergence of this distaste for corporal violence. But not all nineteenth-century shame sanctions involved corporal violence. On the contrary, many nineteenth-century shame sanctions involved the pure public display of the offender, and much nineteenth-century reformist energy was directed against such practices. It is the nineteenth-century campaign against pure public display of the offender that should interest us most today since current American shame sanctions do not involve corporal violence. Yet it is precisely this campaign that we understand least. Historians of punishment have focused much too narrowly on corporal violence.

Nevertheless, with some effort at interpretation, we can understand the Victorian attack on shame sanctions. What nineteenth-century reformers tended to say was that public display of the offender was "indecent," or "brutalizing," or that it reduced humans somehow to "animals." What did they mean by this? Unfortunately, they rarely made their point in any sort of clear analytic way. Take, for example, a passage written by de Molènes, a leading French reformer whose book On Humane Values in Criminal Law ${ }^{88}$ appeared just before the Revolution of 1830, which largely ended shaming practices in France. Molènes confronted a regime of French shame sanctions that included two principal practices: the marque, a kind of branding done on the shoulder of the offender, and the carcan, a cousin of the pillory, which entailed chaining an offender by

84. See Foucault, supra note 67 . I do not mean to question Foucault's admirably wide learning or to deny the subtlety of many of his observations about pure display of the offender See. $6.8 .1 d$. at 106.17 I mean only to say that the primary focus of Foucault's famous argument is the shift from penalizing the body to penalizing the soul-a shift described by Foucault principally with reference to corporal volence See, e.g., id. at $130 \cdot 31$.

85. See Pieter Spierenburg. The Spectacle OF SLFFerIVg 183.99 (198.4) (desenbing the nise of a new sensibility with regard to suffering): Pieter Spterenburg. The Boch and the Siate Earh Hodern Europe, in THE OXFORD HISTORY OF THE PRISON 49 (Nonval Moms \& David I Rothman eds., 1995)

86. See GLENN, supra note 73. For thoughtful discussions of the problem, see, for example. FriED wax. supra note 7, at 74-82; and DAVID GARLAND. PUNISHMENT AND MODERN SOCIETY A STI DY IV SOCIAL. THEORY 229-47 (1990). Garland still focuses largely on corporal volence and on the isth century See ud

87. Moreover, when this Victorian argument is occasionally repeuled today, "t tends to my stufy us Thus, Kahan finds it difficult to grasp why Norval Morrss and Michatel Tonry should regard corporal punishment, in classically Victorian terms, as "brutalizıng" to both the offender and the public See Kahan. supra note 16, at 610 (discussing NORVAL MORRIS \& MICLAEE TONRY. BETWEeY PRISON AVD PROBATION: INTERMEDIATE PUNISHMENTS IN a RATIONAL SENTENCING SYSTEM 6 (1990))

88. De Molènes. De L'Humanité dans les Lois Crivivelliss (Pans. Félıx Locquin 1830) 
an iron neck-collar to a post and exposing him to the public. ${ }^{89}$ Molènes attacked the marque by denouncing its violative way of handling the human body: It was barbaric, Molènes wrote, in an emotion-laden appeal to the modern sensibility, to apply "a red iron to the human skin." the barbarism of branding went beyond the fact that it involved corporal violence; it was barbaric as well, he argued, because branding "assimilates humans to animals." to pursue: the belief that shame sanctions "brutalized." But what exactly did Molènes mean by this belief? He did not say. It is not self-evident that branding is something more properly done to animals than to humans. Molènes's argument that the carcan violated "human dignity," brutalizing both the offender and the crowd that watched, was no more clearly articulated:

It is a scandalous tableau ....

It degrades the human race to deliver it to the gaze of the people in this state of abasement.-Let us renounce this punishment, which is condemned by the values of humanity, which accustoms the populace to tread pity underfoot, which teaches it how one remains brazen in the face of shame, and which makes it forget all sentiments of human dignity. ${ }^{22}$

What did Molènes conceive the "sentiments of human dignity" to be? Why did he (and others of his day) ${ }^{93}$ think that the mere display of the offender "abase[d]" him? He did not say. ${ }^{94}$

Later Victorian authors spoke of the "brutalization" involved in shame sanctions as something that raised, in some vague way, issues of public immorality. William Graham Sumner's 1906 Folkways, ${ }^{95}$ for example, treated the end of public punishment as part of a much grander nineteenth-century evolution toward public "seemliness" and "decency":

\footnotetext{
89. See 3 SAINT-EDME, supra note 81 , at $156-60$.

90. MOLÈNES, supra note 88, at 393 (translation by author).

91. Id.

92. Id. at 401 .

93. The Code Pénal Progessif, for example, quotes the formal government justification for abolition of the carcan:

[T]his punishment degrades the condemned person in his own eyes: He may, before he has been exposed to the public, have retained some feelings of shame; he loses those feelings when he is forced to confront the catcalls of the populace, and the sentiment of his infamy deprives him of the possibility, as of the desire, to regain the esteem of his fellow citizens. As for the public, this punishment, which frightens them, may also deprave them: It extinguishes in them the feelings of charity and pity; it familiarizes them with the sight of infamy.

CODE PÉNAL PROGESSIF, supra note 25, at 125 (translation by author).

94. We find the same sort of silence, about something that apparently seemed too obvious for explanation, in the account of the history of French penal practice by the leading prison reformer Bérenger. See I BÉRENGER, DE LA Répression PÉNALE, DE SES Formes ET DE SES EFFETS 218 (Paris, Imprimeric et Librarie Générale de Jurisprudence 1855) (noting the suppression of public exposition after 1848 but uncharacteristically neglecting to explain the change).

95. William GRAHAM SUMNER, FolKWAYS (Ayer Co. 1940) (1906).
} 
In the Middle Ages very great attention was given to seemliness in the private conduct of individuals. . . Public life, however, was characterized by great unseemliness .... In the fifteenth century a rage for indecent conduct arose. . . Rudeness of manners in eating. dancing, etc., was cultivated as a pose. ... Torture, persecution, violent measures, would all have been impossible if there had been a sense of seemliness. The punishments, executions, and public amusements grossly outraged any human and civilized taste.

The end of public punishment was thus, according to Sumner, part of the rise of "human and civilized taste," part of a larger rise to "decency" in the nineteenth-century public sphere generally. It is, indeed, worth quoting Sumner a bit more extensively to get a fuller sense of his late-Victorian sensibilities of "decency." Sumner's western world was a place whose standards of public behavior had been transformed within living memory:

Decency has to do with the covering of the body and with concealment of bodily functions. Modesiy is reserve of behavior and sentiment. ... Propriety is the sum of all the prescriptions in the mores as to right and proper behavior .... Within a generation the public latrines in the cities of continental Europe have been made far more secluded and private than they formerly were. Within ten years there has been a great change of standard as to the propriety of spitting. ${ }^{97}$

What exactly did Sumner imagine "public decency" to be? What was it, to his Victorian eye, that made the abolition of the "medieval" practice of public punishment akin to the elimination of spitting and the "concealment of bodily functions"? He hardly explained. Sumner, like Molènes, spoke from nineteenth-century assumptions too deep to be articulated.

It can be frustrating, in short, to read nineteenth-century authors-ihey seem to speak of something that matters a great deal, but they do not explain themselves well at all. Nevertheless, there were authors who provided a more articulate picture of nineteenth-century attitudes, especially with respect to the "brutalizing" effect of public punishment on the watching crowd. To Sumner's British contemporary L.T. Hobhouse, for example, writing in Morals in Evolution, ${ }^{98}$ it came down to a question of psychology:

[T] he old rigour, so far as it rested on reason at all, was based on a very crude psychology. People are not deterred from murder by the sight of the murderer dangling from a gibbet. On the contrary, what there is in them of lust for blood is tickled and excited, their

96. Id. at 469-70.

97. Id. at $420-21$.

98. L.T. HOBHOUSE. MORALS IN EVOlution ( $2 \mathrm{~d}$ rev ed. 1908) 
sensuality or ferocity is aroused, and the counteracting impulses, the aversion to bloodshed, the compunction for suffering, are arrested.99

To Hobhouse, public punishment was a bad idea because it stirred up certain base instincts of "sensuality [and] ferocity." The problem raised by public punishment, as he saw it, was part of the great overarching problem of moral psychology: how human beings learned to master their animal instincts. ${ }^{100}$

William Thackeray spoke in much the same frame of mind when in 1840 he described himself as feeling "ashamed and degraded at the brutal curiosity" that had drawn him to a public execution. ${ }^{101}$ Similarly, Francis Wayland, President of Brown University and author of the mid-century The Elements of Moral Science, ${ }^{102}$ argued that public discussion of another's crimes, if done "with pleasure or with a desire of injury," was sinful. ${ }^{103}$ Indeed it was "injurious" to the character of the speaker himself and to anyone who listened. ${ }^{104}$ Wayland's psychology was much like Hobhouse's: "Familiarity with wrong," Wayland wrote, "diminishes our abhorrence of it." 105 It was best to keep the fact of crime hidden, for knowledge of crime tended to corrupt the knower. In this sense, public knowledge of crime was, for Wayland, not all that different from "sell[ing]; or lend[ing], or exhibit[ing] obscene or lascivious pictures." 106 The human mind had a natural tendency toward depravity that exposure to the sinful would tend to unchain. One French reformer put the point in a way that showed how much nineteenth-century lawyers valued their progress beyond the rough sexual justice of the premodern world:

Cruelty in punishment, born of cruelty in the mores of society, makes those mores yet more brutal in turn. ... This is all the more true if indecency is mingled with the punishment in question, if the victim becomes the plaything of the populace, as in the case of certain

99. 1 id. at 113-14.

100. See id. at 11-12. (1840)

101. W.M.T., Going To See a Man Hanged, 22 FraSER'S MAG. FOR TOWN \& COUNTRY 150, 158

102. Francis Wayland, The Elements of Moral Science (Joseph L. Blau ed., Harvard Univ. Press 1963) (1835).

103. Id. at 246.

104. Id.

105. Id.

106. Id. at 241. For an interesting precursor to this 19th-century idea, see the animadversions of I Thorillon, IdÉes sur les loix Criminelles, Ou l'on Propose 460 LotX Nouvelles en Place de Celles QUI EXISTENT Aujourd'hUI 109 (Paris, 1788). Though Thorillon saw much to commend in the publicity of punishment generally, see, e.g., id. at 143-44, he argued that pederasts should be punished in secrecy, see id. As Thorillon wrote: "M. G*** observed to me in this respect, that it is always found that, the more publicity one gave to the punishment of pederasts, the more the offenders multiplied . . .." Id . (translation by author). An early version of this argument, offered by Rush, interestingly assumed that public punishments might deprave if inflicted on the innocent. See RUSH, supra note 74, at 14. 
punishments inflicted on women who had forgotten their role of submissiveness in the family. ${ }^{107}$

Fully exploring these Victorian ideas would take more time than I can give in this Essay. Nevertheless, we can paint at least a general sketch of the worldview of these authors in a few strokes. What they had in common was an honorable nineteenth-century ambition: the ambition to guarantee a higher "spiritual" existence for human beings. Their image of the "civilized" world was much like the image of a "civilized" world that we find in the works of Sigmund Freud. It was a world in which human beings had to struggle hard, and unceasingly, to control animal instincts of "sensuality [and] ferocity." It was a world in which the goal of human social order was to rein in the beast within. The problem with public punishment, according to those who viewed the world in this way, was that it "tickled and excited" bestial instincts. ${ }^{109}$ The display of a criminal paraded base and animal ways, just as public spitting or public urination paraded base and animal ways; all tended to loosen the fetters of decent comportment. ${ }^{110}$

Much of what these authors had to say was thus inevitably about the "brutalization" of the crowd. But their arguments also contained an important dignitary argument about the offender. As Molènes put it, making the offender the center of a public display "abase[d]" him."' Or as Hobhouse put it, making the offender a public example of "sensuality [and] ferocity" reduced the offender to something subhuman;" ${ }^{112}$ it made the offender an embodiment of that above which "decent" society strove to rise.

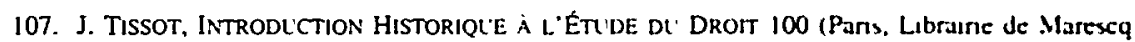
Ainé 1875) (translation by author).

108. 1 HOBHOUSE, supra note 98, at 114: see supra text accompanying note 99

109. Id.

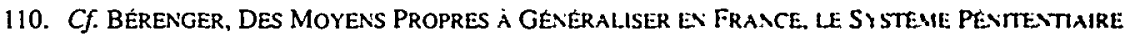
34-35 (Paris, Imprimerie Royale 1836) (describing at great length, and with great indignation. the trooping of near-naked convicts through the French countryside). As Berenger desenbed t, the convicts marched. singing obscene songs, venting ferocious cres, insulting the populations gathenng and pressing around them, and so offering, with all its problems, with all its dangers. for others and for themselves, this hideous tableau of a long publsc expostton throughout our regions. a tableau revolting for all those who witness 11 , and which dangerously troubles consciences that are not sturdy, teaching them that after all, human justice is not as ternfying as they thought and that even expiation has its bright side and its pleasures'

Id. (translation by author).

111. MOLÈNES, supra note 88, at 401 : see supra text accompanying note 92

112. I HOBHOUSE, supra note 98, at 114; see supra text accompanying note 47 Along the same lines. compare the following remarks of de Bastard on the practice of branding:

[T] he goal of all legislation is to develop in man the sentument of that moral dignity that rases him above all the beings of creation; and a punishment that branded that feeling down to its source, that abases the human soul by depriving it of the power to reclam itself. in the eyes of society, from crime and infamy, would run counter to the purpose of the legislator The punishment of the marque does not brand the body alone of the cnminal. It mahes his moral being base and vile....

CODE PÉNAL PROGRESSIF, supra note 25, at 91 (translatuon by author) 
Now, if I have captured the Victorian argument adequately, I think we should acknowledge that it was a deep one, founded in a very subtle psychology. This is true even of Sumner's fascination with bodily functions, as we can see if we reflect upon Max Scheler's revealing late-Victorian account of the phenomenology of shame. Shame, Scheler declared at the outset of a lengthy discussion, involves "a sudden reverting of our attention to the body, that dark constant companion of our existence-a reverting of our attention to the animal-like existence of the body, so narrowly circumscribed in time and space, with its whole crowd of bodily necessities." ${ }^{\text {"13 }}$ From this point of view, all displays of bodily functions and of sinful human tendencies are animal or subhuman. If we can see shame in this Victorian way, we can understand why public display of the offender seemed akin to public spitting. More broadly, we can understand why public display of the offender seemed "indecent." In fact, if we can see shame in this Victorian way, we may develop a sounder grasp of why shame sanctions take the particular ritual forms they do. Premodern shame sanctions did, in fact, have a kind of carnivalesque, orgiastic quality, a quality which suggests a connection between shame and the "bodily functions." Indeed, it is clear that many of the premodern punishments involved more or less explicit symbols of sex and excretion: Offenders were displayed nude, made symbolically to defecate, and otherwise offered up to the public as sexual beings. ${ }^{114}$ The merriment surrounding these punishments was akin to the other public amusements that William Graham Sumner found outrageous. ${ }^{115}$

Moreover, these Victorian insights illuminate more than just premodern public punishments. Indeed, it should be recalled that sexual and "morals" offenses continue to play a prominent role in the shame sanctions of our own society. Current American shame sanctions do indeed exhibit, even define, immoral behavior for us. The Victorian distaste for public shaming that I have described is thus directly relevant to our own current problem. Indeed, if we look at our society through Victorian eyes, we may begin to acquire a deeper sense of why our shame sanctions focus so much upon sex offenses.

Could we, then, revive this dignitary argument against shame sanctions? The Victorians, after all, grasped the dignitary dilemma of existence as an "animal being" in ways that tend to escape us. The Victorian psychologists may also have been right in believing that public display of "immorality" can

113. SCHELER, supra note 48 , at 68 . I should emphasize that there is more to Scheler's argument than I summarize here. I speak only of his efforts to trace the roots of shame to the body, without discussing his efforts to trace the ramifying branches of shame. If we can see the world in Scheler's way, we can grasp why Sumner would think of public shaming as similar to public spitting: Both involved an indecent focus upon "the animal-like existence of the body." Id.; cf. WILLIAM IAN MILLER, THE ANATOMY OF DisGUST (1997) (attempting to show the roots of social organization in forms of disgust).

114. See, e.g., 1 HANS VON HENTIG, DIE STRAFE 413 (1954); sources cited supra note 47.

115. Compare BURKE, supra note 47 , at $197-98$ (describing the "carnivalesque ... performances" accompanying public executions), with supra text accompanying notes 95-97. 
undermine the viewer's self-control. The Victorians, moreover, understood the way in which making the offender a public example of someone who cannot control himself violates that offender's dignity. They mounted what was an honorable effort to found social morality on the maintenance of a carefully patrolled distinction between the human and the animal. What is more, unlike the eighteenth-century reformers, they actually succeeded in eliminating the practice of public humiliation. Could we, then, mount a neo-Victorian critique of shame?

Probably not, for no more complicated reason than that we are no longer Victorians. The belief that we should hide away our sins and our bodily functions is simply gone. Indeed, if we are looking for an explanation for the resurgence of shame sanctions in America, we might well begin with the more general decline of embarrassment about animal functions that has characterized our daily life. We cheerfully expose our bodily functions, constantly speaking, as it were, with our mouths full; we spit in public, and our popular culture draws more and more on the humor of the bedroom and the bathroom. It is part and parcel of these developments that, when we see the names of morals offenders published in the daily newspaper, we experience a kind of premodern merriment where President Wayland of Brown would have asked us to experience embarrassment or disgust. When we see a published list of the names of prostitutes' johns, we gawk without embarrassment. Victorian "spiritual" dignity is gone throughout society; so it is that we remain undisturbed to the extent that shame sanctions deprive offenders of their Victorian "spiritual" dignity. Deep though the psychological arguments of the Victorians were, they help us little, at least in the context of pure humiliation sanctions. To proclaim that shame sanctions cannot be tolerated because they promote an ethic of the display of the human body and of the celebration of bodily existence is, in our society, no more than a non sequitur.

Nineteenth-century ideas of human dignity, however powerful they may have been, are thus not likely to do us much good in explaining the ill of shame sanctions today. We have lost the world of Victorian bodily delicacy as completely as we have lost the world of established social hierarchy.

\section{THE Christian TRADITION}

Whatever shifts may have occurred in our social psychology, the fact is that the leading classical liberal arguments from dignity do not seem to carry much weight any longer. What else is there? Seeking other classical arguments against shame sanctions, we can move a step away from the classical liberal tradition toward something of a different tenor and with a longer history: the Christian tradition. Here we can identify an uncommonly provocative Christian claim, namely that there is a tradeoff between shame and guilt and that it is better for the penal system to instill the latter than the former. The problem 
with shame sanctions, on this Christian line of argument, is that they are not guilt sanctions.

This line of argument is much older than anything I have considered so far in this Essay. The idea that public shaming should be replaced by private penance is one that has recurred periodically over the long history of western Christianity. It may indeed date back to the early Middle Ages, and perhaps even earlier. ${ }^{116}$ Certainly, it is possible to trace the Christian drive to eliminate public shaming to the confessional revolution of the thirteenth century, when the Church made a concerted effort to establish private confession as its normal means of maintaining moral discipline. ${ }^{117}$ The place to discipline offenders, on this view, was not in public but in the "internal forum" of the conscience, where the penitent could hear the voice of God and amend his conduct. Christians sharing this view saw public shaming as a danger many centuries before the French Revolution.

Not surprisingly, this long Christian tradition of favoring private penance over public humiliation has played a role in the decline of western shame sanctions. ${ }^{118}$ The influence of this tradition is evident, for example, in the work of the earliest enlightened opponent of shame sanctions whom I have been able to identify: G.G. Titius of Leipzig, who tried in the early eighteenth century both to reorder the law of the Protestant churches and to bring about an abolition of public humiliation. ${ }^{119}$ The influence of the Christian tradition is evident as well, however, in much of the agitation of the great era of reform, decades after Titius wrote. This is particularly true, of course, with respect to the movement to establish the penitentiary, especially in Pennsylvania where,

116. See generally Henry Charles Lea, A History of Auricular CONFEssion ANd INDUlgences IN THE LATIN ChuRCh (Greenwood Press 1968) (1896); JOHN T. MCNEILL \& HElena M. GAMER, Medieval Handbooks of Penance 4-50 (Columbia Univ. Press 1990) (1938).

117. See Mary C. Mansfield, The Humiliation of Sinners 1-17 (1995); John Bossy, The Social History of Confession in the Age of the Reformation, in 25 TRANSACTIONS ROYAL HIST. SOC'Y (5th scr.) 21 (1975).

118. See IGNATIEF, supra note 45 , at $44-79$.

119. See Titius's annotations in Samuel PUfEndorf, De OfFicio Hominis et Civis SeCundum LEgem Naturalem LIBRI DUO, CUM OBSERVATIONIBUS Ev. OTtONIS ET GOTTL. Gerh. TITII 822 n.g (Leiden, Luchtmans 1769). As Titius wrote: "[A]n absurd form of punishment that, when it is inflicted on the living, does not emend the delinquent, but rather renders them unfit for acting rightly." Id. (translation by author). One can see in this passage, specifically in the term "emend," the Christian beginnings of what would become the familiar sociological argument. See also Ernst Landsberg, G.G. Titius, in 38 ALLGEMEINE DEUTSCHE BIOGRAPHIE 379 (Dunkner \& Humblot 1971) (1894) (discussing Titius's campaign against shame sanctions). The Christian content of Titius's argument is reflected clearly in Thomasius's response to Titius. See Thomasius, AN POENAE VIVENTIUM, supra note 80 , reprinted in 4 DISSERTATIONES, supra note 80 , at 546 . Thomasius asked whether Titius's views were not simply those of an Arminian and a natural law Lutheran of the style of Wittenberg. See id. For another text of the period, apparently from Wittenberg, which attempts to develop a Protestant foundation for the rejection of shame sanctions, see JUSTIN CLEMENS, GEWISSENHAFTE ANMERCKUNGEN VON DEM AMTE EINER CHRISTLICHEN OBRIGKEIT/SONDERLICH DIE IN BEZIEHUNG AUF GOTTLICH- UND WELTLICHE RECITTE EINGEFÜHRTE STRAFFEN DER UBELTHÄTER BETREFFEND: ALLEN CHRISTLICH-GESINNTEN RICHTERN UND RECHTS-GELEHRTEN/AUCH WARHETT-LIEBENDEN THEOLOGEN ZU REIFFEM NACHSINNEN IN BESCHEIDENHIEIT VORGELEGET (n.p. 1698). 
under Quaker inspiration, ${ }^{120}$ the most famous of schemes to take the offender out of the public eye and leave him alone with his conscience was born. ${ }^{121}$ This movement was inextricably bound up with the decline of shame sanctions: The penitentiary movement conceived of and presented itself as an enlightened, Christian alternative to the older system of shame sanctions, one that would replace the primitive order of public display and shame with a modern order of isolation and guilt. ${ }^{122}$

What is left of this once powerfully influential line of argument? Very little, and for several reasons. First, and perhaps foremost, this argument more than any other has run aground on our experience of prisons. There are surely very few people who believe any longer that prisons serve as "penitentiaries" of the kind they were intended to be, as places of monastic isolation where the quiet, persistent voice of the offender's conscience would teach him to know guilt.

Even beyond the practical failure of penitentiaries, however, the Christian argument rests, like others I have discussed, ${ }^{123}$ on a notion of shame that is no longer easy to accept. The idea that shame is public whereas guilt is private is an idea that has been very widely abandoned. Nor do all psychologists believe that there is a necessary tradeoff between the two: that a person tends to experience either shame or guilt alone. ${ }^{124}$ Similarly, cultural anthropologists and historians have retreated from the view that there is a sharp distinction between "shame cultures" and "guilt cultures" and that the first tend to metamorphose into the second as norms once enforced through public shaming are internalized. ${ }^{125}$ Most social scientists now view shame and guilt as generally coexisting and see comparatively little use in thinking of "guilt" as "internalized shame."

Even leaving all that aside, the old Christian argument cannot serve our needs any longer for the simplest of reasons: Our society is no longer the sort of Christian society it once was. Perhaps, if we were all believing Christians, we might accept a view of guilt as an emotion experienced only in isolation. Perhaps we might view the morally lesser "public" experience of shame and

120. See, e.g., IGNATIEF, supra note 45 , at 58-59.

121. Indeed, most of the early penitentuaries, which aumed to place the offender in something equivalent to the monastic penitential cell. were avowedly Chnsuan (and all of them were at least recognizably Christian). See id. at 44-79.

122. See id.

123. See supra text accompanying notes $51-52$. (1988)

124. See, e.g., Peer Hultberg, Shame-A Hidden Emohon. 33 3. ANal.rTiCal. PsycuOL. 109. $115-16$

125. See PIERS \& SINGER, supra note 48, at 60-61 (notıng that Indian culture. a supposed "shame culture," possesses patterns of guilt): WiLLIANiS, supra note 52. at 91 (discussing the compleviltes of the idea of a "shame culture"); Huliberg, supro note 124. at 113.14 (discussing the impossibility of distinguishing between shame and guilt cultures). For examples of the old approach. see RLTH BESEDICT. ThE Chrysanthemum AND the SWORD 222-24 (1946): and E.R. DODDS. THE GReEks AND the IRRATIONAL 17-43 (1951). 
the morally greater "internal" experience of guilt as true alternatives. But we are not, collectively at least, believing Christians of that kind.

\section{Political ARguments}

The arguments against shame sanctions I have touched on so far could be called social arguments-arguments about the deep structure of social relations, about matters that stand outside the ordinary purview of political theory. Let me now turn to more conventional political arguments-in particular, to the great liberal political thinkers, Wilhelm von Humboldt and John Stuart Mill, their not-entirely-liberal precursor Jean-Jacques Rousseau, and their statistauthoritarian counterparts as well.

We have seen that the classical arguments focusing on the need to abolish shame sanctions as a matter of social reform no longer seem to carry weight. Society has changed too much since the early nineteenth century-and changed, arguably, in precisely the ways that have made the resurgence of shame sanctions possible. We put little effort into raising ourselves above the animal life of our bodily functions; outward status distinctions, if they still survive, are so hazily perceived that we can hardly describe them; and the grip of Christianity on our society, or at least of a Christianity strongly oriented toward the individual conscience, has been very deep!y shaken. The ideas that shame sanctions are physically "abasing," socially undignified, or inimical to the inculcation of guilt, have lost much of their force as a result. In the 1840s, it was obvious to enlightened persons such as Molènes that inflicting shame sanctions was an illiberal way of treating offenders, but today the same thing is no longer obvious at all. We have lost too much of the sense that shaming others is not a decent way to act.

Let us then turn away from what I have broadly called social reformist arguments, toward the more familiar sort of political reformist argumentsarguments about the wise and proper use of state power. Here we do well to begin with the classic statist-authoritarian argument of the European tradition before we come to the classical argument of European liberalism.

The statist-authoritarian argument grew out of the experience of statebuilding. It is an argument purely about policing: Exposing offenders to the public, the argument runs, is likely to excite the crowd so much that it causes rioting, and when there is rioting, the state loses control. Strains of the argument recurred throughout the eighteenth century in both the United States and Great Britain, particularly in connection with public executions; the history of this argument in the Anglo-American world has been much studied. ${ }^{126}$ But

126. See, e.g., IGNATIEFF, supra note 45 , at $23-24$ (questioning the efficacy of public hangings at Tyburn as a deterrent because they inverted the ritual "from a solemn act of the state to a popular bacchanal"); 4 RADZINOWICZ, supra note 82, at 345 (quoting Mandeville in 1725 warning that the frequent executions at Tyburn were "exemplary the Wrong Way"). For an excellent treatment of the history of 
it is important to trace this argument in the long history of Continental Europe too, where the abolition of shame sanctions was more official and more permanent and where concerns about crowd management were more consistently articulated in contexts other than public executions.

Some of the most striking arguments on this front were French ones. The theme of crowd control was not the issue of the day in eighteenth-century France, where critics of shame sanctions focused on very different problems. ${ }^{127}$ But the crowd control theme became important during the most intensively abolitionist period in France, from around 1825 to 1848 . For example, it was argued during the debates after the Revolution of 1830 that shame sanctions were not suitable for use in large cities: While in the countryside they made a "profound and solemn impression," in the cities they "excited the evil passions of the populace," creating difficult problems for the police. ${ }^{128}$

This style of authoritarian argument could be found, in subsequent decades, in other parts of Continental Europe as well. It enjoyed a particularly interesting career in Nazi Germany. ${ }^{129}$ It is hardly surprising that various Nazis and Nazi sympathizers were eager to see shame sanctions reinstituted. Shame sanctions fit, after all, the general national socialist spirit of parade, display, and humiliation. In addition, they fit the spirit of the Nazi order that included both dramatic public rallies and the enforced wearing of badges like the yellow star. ${ }^{130}$ At the time of the Nazi seizure of power, prominent legal thinkers, such as Georg Dahm, began to propose shame sanctions as the natural enforcement technique of an antiliberal society. ${ }^{131}$ As Dahm saw it, where liberty had been the highest good of the old liberal order, honor was now the highest good of the new Nazi order. ${ }^{132}$ Shame sanctions, which deprived offenders of honor, should accordingly be the Nazi punishment of

public executions, see Steven Wilf, Lnagining Justice: Aesthencs and Public Execuhons in Late EighteenthCentury England, 5 YALE J.L. \& HUMAN. 51 (1993).

127. The dominant complaint with respect to shame sanctions in 18 th-century France seems to have been that shaming afflicted not only the offender, but also the offender's family. See. e $g$. LACRETELLE. supra note 80 , passim; VOUGLANS, supra note 69. at 836.

128. CODE PÉNAL PROGRESSIF, supra note 25, at 126 (translation by author), $c f$ ud at 130 (remarks of Félix Réal) (admitting that shame sanctions are likely to be more effecuve in provincial selungs. but nevertheless seeing dangers in inflicting them even there). The same observation can also be found in FIELDING, reprinted in THE COMPLETE WORKS OF HENRY FIELOING, supra note 80, al 122

129. The story here is, as far as I can discover, little studied. Cf. e.g. INGo Mlluer. HmLer's JUSTICE: THE COURTS OF THE THIRD REICH 78-79 (Deborah Lucas Schneıder trans., Han ard Univ Press 1991) (1987) (discussing the advocacy of shame sancuons by promunent Nazi scholas but negleetung to note that, in practice, such shame sanctions did not ultimately come into use)

130. See ESSER, supra note 24, at 72 (discussing the yellow star used by the Nazis to identify Jews) For the use of pillorization by the Nazis against Jews in panicular, see RICHARD LAWRESCE MILLER. NAZI JUSTIZ 60-64 (1995).

131. See Georg Dahm, Die Erneuerung der Ehrenstrafe. 39 DELTSCHE JL RISTEV.ZEITL VG 821. 826-27 (1934); see also HERBERT MANTLER, ENTWICKLUNG UND BEDELTINGSWANDEL DER EURENSTRAFE SET BEGINN DES NEUNZEHNTEN JAHRHUNDERTS, UNTER BESONDERER BERLCKSICITIGL YG DER NATIONALSOZIALISTISCHEN STRAFRECHTSREFORM 56-64 (1936).

132. See Dahm, supra note 131 , at 827. 
choice. What was promoted by university Nazis like Dahm was also promoted by back-alley Nazis like the followers of Ernst Röhm. The Sturmabteilung (SA), the brownshirted Nazi private army, made attempts in 1933 and 1934 to reintroduce the pillory and other shame sanctions, grabbing offenders and subjecting them to various kinds of medievalizing public humiliation. ${ }^{133}$

In early 1934, as all this transpired, one might have supposed that shame sanctions would become the Nazi norm. Nevertheless, strikingly, the authoritarian tradition won out. By the mid- and late-1930s, it became clear that Nazi legal opinion would not tolerate pure humiliation sanctions. To be sure, Nazi legal thinkers promoted a wide range of punishments intended to diminish the "honor" of the offender, ${ }^{134}$ but they rejected pure humiliation sanctions in terms that provocatively mixed the language of statism with the language of Victorian moralizing. Thus, Roland Freisler, a leading Nazi jurist and functionary, congratulated the SA in 1934 for having performed the "service" of reintroducing medievalizing shame sanctions, a "very effective form of punishment." 135 Nevertheless, he opposed any full-scale use of such sanctions done in any way except under supervision of the state. "There exists the danger," he wrote, "that it will become a public entertainment for part of the population." 136 Good Nazi legal practice could not countenance the reappearance of the carnivalesque law of the Middle Ages. Freisler proposed, instead, that criminals be exposed before the place of judgment, where "disciplined organisations"-presumably Nazi brownshirts-could march before them in formation. ${ }^{137}$ Others too thought that it was better to avoid problems by conducting humiliation ceremonies only in the presence of SA and Schutzstaffel (SS) troops, keeping the public out. ${ }^{138}$ Anything else, explained one author, in a weird echo of Victorian moralizing, would arouse "base instincts" and lead to "brutalization and the desire to gawk" in public. ${ }^{139}$

These Nazi concerns were not precisely those of eighteenth-century England or of nineteenth-century France; the threat that these Nazis perceived was less the threat of a riot than the threat of a carnivalesque revel. Nevertheless, despite their differences, the Nazis did belong to the statist

133. See LOTHER GRUCHMANN, JUSTIZ IM DRITTEN REICH 1933-1940: ANPASSUNG UND UNTERWERFUNG IN DER ARA GÜRTNER 336-45, 376-77 (1988).

134. See ALFRED KeTtEleR, DIE ERNEUERUNG DER EHRENSTRAFE 50 (1937) (explaining the honor content of different Nazi execution practices).

135. Roland Freisler, Strafensystem, in DENKSCHRIFT DES ZENTRALAUSSCHUSSES DER STRAFRECHTSABTEILUNG DER AKADEMIE FUR DEUTSCHES RECHT UBER DIE GRUNDZUUGE EINES ALLGEMEINEN DEUTSCHEN STRAFRECHTS 100, 113-14 (Freisler \& Luetgebrune eds., 1934) (translation by author).

136. Id. at 114 .

137. Id. 56.

138. The Akademie für Deutsches Recht made one such proposal. See KETTELER, supra note 134, at

139. Id. (translation by author). 
tradition: They too, like the nineteenth-century French, worried that public shaming would undermine the ability of the state to control the crowd.

Statist policing concerns were obviously very powerful-powerful enough to overcome strong ideological tendencies even among the Nazis. Should the same policing concerns also inform our thinking in America today? I am going to end by suggesting that, in fact, there is some real wisdom in this Continental policing argument. But for the moment let me make the obvious point that, in its pure original form, the classic policing argument does not carry much weight in American discourse. We are certainly concerned about urban rioting. We are, moreover, particularly concerned about riots caused by acts of the legal system, as the recent history of Los Angeles shows. If, therefore, we were to imagine that the problem faced by French and German administrators is not our problem, we would be wrong. One need only consider the crowd management problems that might result from the imposition of shame sanctions on, for example, African-American offenders in Los Angeles to recognize that the risk of riot is real.

Nevertheless, I take it that in the American tradition, there is a consensus that the government cannot permit itself to be guided in its decisionmaking by fear of riots. Unlike lawyers in the Continental world, we are not prepared to think that the imperative of maintaining order alone justifies any particular method of applying justice. Crowd management, for us, is an incidental problem that may be created in the pursuit of the right and just result. If inflicting shame sanctions seemed to us, on independent grounds, the right thing to do, I take it that we would inflict them even at the cost of rioting. which we would attempt to control by other means. Indeed, such has been our recent history with respect to various laws like Megan's Law in New Jersey, ${ }^{140}$ which have been passed (and upheld) despite the acknowledgement that vigilantism is a real danger. ${ }^{\mid\lrcorner 1}$ On a deeper level, perhaps, we are far less willing than the Germans or the French to deny the crowd its say, even its violent say.

If the authoritarian political argument seems weak in the American context, the same is perhaps not true of the last argument that I will review here: the classical liberal political argument. We can trace from Rousseau (odd progenitor of a liberal tradition though he may seem) through Humboldt to Mill the claim that the government can never in practice succeed in imposing shame. This classical liberal argument is akin, in some ways, to the argument

140. Registration and Community Notification Laws. N.J. STat ATI. \$\$ 2C 7.1 $10-11$ (West 1995 \& Supp. 1997).

141. See, e.g., Russell v. Gregoire. No. 96-35398. 1997 U.S App. LEXIS 23074, at *29 (9th Cir. Sept 4. 1997) (discussing Wash. REv. CODE $\$ 4.24 .550$ (1) (1990)): E.B. V. Verntero. 119 F $3 \mathrm{~d} 1077$ (3d Cir 1997) (discussing New Jersey's Megan's Law); $1 d$. at $1089 \mathrm{n} .7$ (munumizung the relesance of instances of "harassment" of released offenders); see also Kreimer. supra note 57, at 39-42 (noung that disclosure rases the possibility of private violence). 
from modernity, for it is also an argument from impossibility. But the classical liberal thinkers, unlike the sociological advocates of the argument from modernity, did not believe that there could be no shame-based enforcement in modern society. On the contrary, they believed that shame remained a highly effective tool of enforcement, even in modern western societies. But they held that shame was an enforcement tool to be used by society alone, not by the state. Indeed, in its classic form, as developed by Rousseau (in a famous, and characteristically elusive, passage from Letter to $M$. d'Alembert on the Theatre ${ }^{142}$ ) and any number of followers, ${ }^{143}$ this argument held that the state's efforts to impose shame might even backfire. The state could never order members of society to regard private persons either with respect or contempt, for public opinion formed its own judgments about the merit of private persons, judgments over which the state could not have the slightest influence. ${ }^{144}$ Humboldt offered a classic declaration of this idea in his The Limits of State Action, ${ }^{145}$ and Humboldt's influence shows in a work he famously influenced, Mill's On Liberty ${ }^{146}$ in which Mill sought principally to explain the proper disciplinary roles of public opinion and the law, respectively. ${ }^{147}$

Such is the grand old liberal argument. There is certainly some strength in it; I will say in a moment where I think that strength lies. But the argument also contains some considerable weaknesses. First, anyone who has lived in the twentieth century has to be less sure of the stability and independence of public opinion than these liberal writers were. Rousseau, Humboldt, and Mill lived before the Nazi period and, more broadly, before the advent of modern mass politics and the modern media. They had little conception of how dramatically propaganda and publicity can manipulate public opinion-not only propaganda like the anti-Semitic writings of the Nazis, but also such images as the televised arrests of Wall Street traders. ${ }^{148}$ Modern propaganda may, in the end, fail to achieve its intended effect, but its effect remains strong quite long enough to destroy many individual lives. Moreover, in a modern society, there is no defined "public" circumscribed enough to form discrete opinions about most particular individuals; it is simply not the case that a person

142. Jean-Jacques Rousseau, Politics and the ARTS: LetTer to M. D'Alembert on the THEATRE 67-75 (Allan Bloom trans., The Free Press of Glencoe, Ill. 1960) (1758) (discussing the difficulty of guiding public opinion in the context of the campaign to repress dueling).

143. For the influence of Rousseau's argument, see, for example, NIOCHE, supra note 72, at 62-63; and THORILLON, stura note 106, at 65.

144. A measure of the degree to which this idea could be vulgarized can be taken from BOITARD, supra note 43 , at 53 . For an elegant statement by a great German jurist, see KARL BINDING. DIE EHRE IM RECHTSSINN UND IHRE VERLETZBARKEIT 22 (Leipzig, Alexander Edelmann 1890).

145. HUMBOLDT, supra note 74 , at 112 .

146. JoHN STUART MILL, ON LIBERTY (David Spitz ed., W.W. Norton \& Co. 1975) (1859).

147. See, e.g., id. at 70 (explaining when offenders may "be justly punished by opinion, though not by law").

148. See supra text accompanying note 55 . 
shamed by the state can count on the public to recognize his true innocence and honor. But even if this were the case, the classical liberal argument would be powerful only with respect to the government's power to punish those deemed by society, for whatever reason, innocent. Such cases may exist, but they surely comprise a tiny minority that should not guide our routine thinking. There is something amiss in any theory of punishment that begins by denying that the offender is guilty.

\section{CONCLUSION}

All of this leaves us-leaves me at any rate-in a state of some intellectual embarrassment. We feel $-I$ feel-an intuitive certainty that there is something disturbing about shame sanctions, that shame sanctions somehow diminish the offender's dignity in the wrong way and that they somehow make the wrong kind of appeal to the crowd. Yet we can spend a great deal of time rummaging through the grand old arguments against shame sanctions and still come up short.

So what is the argument against shame sanctions?

Let me pull together a few strands from the various arguments that I have touched on and try to weave out of them something that seems right. First, there are two aspects to what is troubling about shame sanctions: their effect on the offender and their effect on the crowd. We tend, in our rights-oriented society, to begin by reasoning from the first. But let us try to begin our reasoning from the second.

The classic political objections we have just reviewed agree on one proposition: The government cannot control fully the actions and the affect of the crowd as it wishes. Such is the liberal tradition of Humboldt and Mill; such, for that matter, is the statist tradition to be found in France and Germany. There is an important difference, though, between the two: Whereas the liberal tradition tends to hold that the government cannot control the opinions of the public, the statist tradition tends to hold that the government cannot control the actions of and the effect upon the public. The liberal tradition holds, as it were, that the public will tend to remain an unmastered public; the statist tradition holds that the public will tend to become an uncontrollable mob. The liberal tradition imagines a public with well-educated moral sensibilities, with the deep reserves of self-control of a Calvinist congregation, and with the ability to form its own judgments about miscreants. The statist tradition, by contrast, imagines a public that is always ready to riot. $^{149}$

149. Mill, it should be noted, was closer to the statist tradition in this sense than Humboldt was See MILL, supra note 146, at $68-69$ (expressing a suspicion of the mass public) 
The experience of the last century has made the liberal version of this tradition seem dubious. It is difficult, in light of some hard experience, to believe that the state cannot succeed in destroying reputations. It is hard, more generally, to believe that the state cannot succeed in stirring up the passions of the crowd against individuals. It was the very policy of Maoist shame sanctions, for example, to do exactly that. Nor need we go as far afield as China. We need speak only of our country's own practices. Does anyone really doubt that our own shame sanctions, whether directed against sex offenders or drunk drivers, have some impact on "public opinion" about that person?

The statist version of this tradition, by contrast, still seems to have a kernel of truth in it. Once the state stirs up public opprobrium against an offender, it cannot really control the way the public treats that offender. Indeed, in the most controversial area of current American practices, the sexual predator notification statutes of the Megan's Law type, debate has come forcefully, and I think rightly, to revolve around the risk of lynching in various forms. ${ }^{150}$ The government, in this context, may indeed create something akin to riots, as in the painful case in which an innocent man was assaulted by attackers who wrongly supposed him to be a released child molester. ${ }^{151}$ But I do not wish to rest my argument on the danger of literal riots, for it is essential that we grasp what is wrong even with far less dramatic cases than the sorts of child molestation that are the usual stuff of laws like Megan's Law. Even where there is no threat of rioting, the state has no control over the sort of abuse the public will deal out to a shamed offender. When our government dangles a sex offender or a drunk driver before the public, it has vanishingly little control over how the public treats the person. Riots are by no means the only danger. Other things happen too-things that are more difficult to detect and therefore more disturbing. Who knows how private persons will treat the shamed john, the shamed merchant, the shamed shoplifter, the shamed drunk driver? Who knows how private persons, given the right to play policemen, will behave?

It is here, I think, that we begin to approach the heart of what is troubling about shame sanctions: They involve a dangerous willingness, on the part of the government, to delegate part of its enforcement power to a fickle and uncontrolled general populace. Even in their mildest American form, shame sanctions amount to a kind of posse-raising legal politics, with all of the risks

150. See supra note 141 and accompanying text.

151. See Jon Nordheimer, 'Vigilante' Attack in New Jersey Is Linked to Sex-Offenders Law, N.Y. TIMES, Jan. 11, 1995, at Al. But cf. Andy Newman, Megan, Her Law and What It Spawned, N.Y. TiMES, Feb. 25, 1996, § 13 (New Jersey), at 1 (quoting the New Jersey Attorney General stating, "We've done 86 notifications and had only one reported act of vigilantism"). For less dramatic examples of lynch justice, see John T. McQuiston, Sex Offender Is Suing His Neighbors over Protests, N.Y. Times, June 20, 1997, at $\mathrm{BI}$ (describing rallies held to protest the presence of a sex offender in the community, an incident in which a brick was thrown through the ex-offender's car window, and harassing calls to the ex-offender's employer). 
that implies. They are, at base, a form of officially sponsored lynch justice, ${ }^{152}$ meted out by courts that have given up on the obligation of the state both to define what is criminal and to administer criminal sanctions itself.

Of course, it is easy to understand how courts have come to this point. We all believe the state is doing a bad job of administering criminal sanctions and that our prisons, in particular, are lousy institutions. Why not tum certain limited classes of offenders over to the public? Why not discipline sexual misbehavior, commercial misbehavior, and the like, through techniques of humiliation that are often likely to be effective and to bring many offenders into line with what we think are norms of public comportment? Why not turn such offenders over to be judged by the established norms of public opinion?

The right answer, I think, recognizes shaming as a form of lynch justice and acknowledges both the personal and the political dangers that stateencouraged lynch justice raises. The right answer acknowledges three things: first, that it is a mistake to imagine that there are established norms of public opinion that go unaffected by state shaming; second, that we have far too little control over the way the public exercises its enforcement power-far too little control over the tendency of the public to become either a mob or a collection of petty private prison guards; and third, that allowing state-encouraged lynching involves a troubling tolerance for ochlocracy, for a democratic government too susceptible to the pitch and yaw of mob psychology. Particularly where shame sanctions are applied in the realms of sex and commerce, they represent a misguided willingness to let the business of government devolve to an over-volatile public-to make, in the words of a nineteenth-century reformer, their victim a "plaything of the populace."153

With respect to the first point, it is simply wrong to suppose that the shaming state is not a maker of public norms. This is not because the American government engages in propaganda of the Nazi or Maoist kind when it inflicts shame sanctions. The process is subtler than any kind of calculated propagandizing, but it is a powerful process nevertheless. Government actions like shame sanctions change public norms; and, let us not fail to note, public officials often seek to employ shame sanctions in order to change public norms. Is the only effect of publishing the names of prostitutes' johns to expose them to an existing atmosphere of condemnation? Or is the effect to nudge prevailing views in a new, more moralistic, direction-or even simply to consolidate what had hitherto been a more vague and less effective consensus? Are officials who advocate publishing the names of johns simply seeking more effective enforcement measures? Or are they promoting greater

152. For the idea that shame sanctions are a varicty of lynch justice (though without the political ramifications I discuss here), see Gustav Radbruch, Der Ueberaeugungsverbrecher, 4 ZETTSCHRIFT FUR DIE GESAMTE STRAFRECHTSWISSENSCHAFT 34. 36 (1924). which describes shame sancions as a form of "moral lynch justice."

153. TISSOT, supra note 107, at 100; see supra text accompanying note 107. 
political legitimacy for themselves by stirring up some mix of public indignation and public merriment? Is the only effect of publicly shaming Wall Street traders to draw on an existing body of righteous public indignation? Or is it to create, or enhance, a public sense that something sinister is afoot in the financial world and so to stir up the sort of politically powerful anti-banker sentiment that has characterized so much of modern politics (especially in its anti-Semitic incarnations)? These are unavoidable issues in any scheme that involves the dangling of sexual, commercial, and first or minor offenders before the public. Playing with public opinion on dark and volatile psychologies like the psychologies of sex and commerce makes for a distressingly creative politics, a politics of the dark and the volatile. ${ }^{154}$ It is a form of legislating and politicking in the realm of morality that goes unchecked by any of our standard ideas about the propriety of legislating or moralizing. It is a stirring up of the public-who knows whither?

It is also a stirring up of the public in who knows what way. The numberless private policemen who enforce shame sanctions play by their own rules or by none. This is a pressing problem and a problem best understood by coming at last to the question of how shame sanctions violate the dignity of the offender. For the dignitary claim I would like to defend is this: Subjecting offenders to the public's unpredictable response to shame sanctions is a violation of our modern sense of what we might call transactional dignity. It is a deeply rooted norm of our society that persons should never be forced to deal with wild or unpredictable partners. We have a sense that no one should be compelled to dance with a madman, that no one should be compelled to trade except under well-understood rules of trading. This is something very different from bodily dignity, something different from status dignity. It is, as it were, marketplace dignity. It is the dignity involved in having the right to know what kind of a deal one has struck, and on what terms. It is the dignity of the one-shot transaction - the dignity that arises from our marketplace right to complete one deal and move on to the next one, the dignity that comes from our right to pay off a debt once and for all and be done with our creditor. ${ }^{155}$

When the state turns an offender over to the public, it robs him of that transactional dignity. There is no way to predict or control the way in which the public will deal with him, no rhyme or limit to the terms the public may

154. This objection is touched upon in the title, but disappointingly little in the text, of Kenneth Crimaldi, Note, "Megan's Law": Election-Year Politics and Constitutional Rights, 27 RurGers L.J. 169. 204 (1995). For an elegant discussion of the broader constitutional problems raised by government disclosure, with an emphasis on the demagogic dangers revealed by the experience of the McCarthy era, see Kreimer, supra note 57, at 15-25.

155. What I have called "marketplace dignity" could also be conceptualized differently. The law, we might say, must always choose between characterizing transactions and characterizing persons. The problem with shame sanctions, as I have described them here, is that they characterize the person rather than the offense. They consign the offender to a new, lesser status. In this sense, they exclude the offender entirely from the life of ordinary transactions, just as members of shunned classes are excluded everywhere from the simple dignity of admission to the marketplace. 
impose. Shame sanctions, in this regard, are very different from prisons or fines. However much prisons may have declined into chaos, they are in principle controllable. However monstrous they may have become, we all agree that the state has the duty to manage them: to establish rules, to call review boards, to answer complaints in court. None of that apparatus exists to control the enforcement of shame. This means that, though courts may wish to abandon the prison system and switch to a system of shaming, they must not be permitted to do so. Doing so means abandoning their obligation to maintain a monopoly of the means of power-it means abandoning their duty to be the imposers of measured punishment.

Shame sanctions thus do represent a deprivation of dignity in a sense that is meaningful for our society, and perhaps that is enough to resolve the question. But there is more to the matter than that, and I would not like to end by speaking of the offender's dignity. It is important, even at the risk of sounding what may seem a wild alarm, to recognize that public humiliation of offenders is a politically questionable practice. If we focus only on the offender's dignity, we will never be able to answer the question that should trouble us most: What is it about shame sanctions that made them appealing to Maoists, to the Taliban, to the Nazi SA? What is it that made them appealing to the very movements that define political illiberalism for us?

The answer has to be that shame sanctions lend themselves to a politics of stirring up demons-as the SA tried to stir up demons and as Mao tried to stir up demons. Shame sanctions belong to a style of twentieth-century mass politics that draws its power not from a sober public, but from a fired-up crowd. Innocent though shame sanctions may often seem in our own country, they carry all the dangers of a demagogic democratic politics. Of course, we are not likely to have fascism or Maoism here. Nevertheless, it remains a condition of democratic rule of law, and of the right of a democratic society to punish, that we shy away from mob politics. In defining ourselves as a liberal society, as a society different from Maoist or Nazi society, we must accordingly remain conscious of the dangers of demagogic politics-conscious of the impropriety of any kind of official action that plays on the irrational urges of the public. ${ }^{156}$ We must remember something that was apparent to all in the nineteenth century: Democracy is never a proper form of government unless it can count on a sober and disciplined populace. Displaying morals offenders, commercial offenders, or first and minor offenders invites the public to rummage in some of the ugliest corners of the human heart. That cannot be good for healthy politics.

156. Cf. Stanley S. Arkın, What Other Nations Can Teach About Crminal Justice. N Y. LJ , Feb. 13. 1997, at 3 ("The severity of sentences imposed in the United States is much more similar to a country like the People's Republic of China than it is to other industnalized democracies. To some extent. after all. a nation can be judged by the company 1 keeps."). 
All of this provides a metric for judging shame sanctions as they appear in our country. To the extent such sanctions proclaim the message that the public is to serve as the agent of punishment, they will always run counter to the norms of democratic rule of law. By this metric, we can determine which shame sanctions are troubling, and how troubling they are. The most disturbing shame sanctions are those that convey the message that government has abandoned its monopoly of the power to punish crime, allowing the public to do with the offender as it sees fit. The shame attached to a prison sentence is, by this measure, comparatively untroubling; for a prison sentence, by its nature, announces the government's ultimate refusal to abandon the power to punish. ${ }^{157}$ Shame sanctions are most objectionable, however, where they most encourage the public to punish in an undisciplined and unthinking way. ${ }^{158}$ This means that they are especially objectionable when they are inflicted in the sensational and politically charged realms of sex and commerce, realms in which the public in mass democracies can lose its bearings, just as village societies did in the premodern world.

It is essential that we carve out a realm of the political that is not about dark psychologies of sex, not about dark suspicions directed against commerce and money. It is essential that we carefully limit the powers we confer upon the public to questions upon which the public can pass in a spirit of sanity and good sense. That is why we limit the business of inflicting criminal sanctions to criminal justice professionals. We have worked, over two liberal centuries, to build an ethic of businesslike politics that denies our officials the authority to pluck on the bass strings of public psychology and that makes criminal law the province of trained and disciplined officers. Over many generations of ugly experience, we have worked to build a democratic government that acknowledges the importance of an ethic of restraint and sobriety. The new shame sanctions tend to undermine that ethic, and that is a disturbing thing.

157. It is by this standard that we can distinguish various forms of the public listing of offenders' names. The listing of offenders' names by the government is most objectionable where it most invites undisciplined punishment by the public and where the government has effectively renounced its monopoly over the punishment power with respect to those persons. The listing of the names of prostitutes' clients is inappropriate, by this standard, both because it effectively abandons punishment to the public and because it does so in the dangerous and undisciplined realm of sex. The listing by the government of the names of other sorts of convicted persons may not, by contrast, be troubling at all, if the purpose of such listing is simply to incapacitate the offenders in question and if the government implicitly retains its ultimate right to punish. Moreover, the listing of names by nongovernmental officials is not objectionable by this standard, since it does not involve the surrender of any governmental criminal punishment power. In this sense, my argument is a kind of antidelegation doctrine. The great danger lies in the delegation of criminal punishment powers to the general public.

158. My objections become, of course, less cogent to the extent that the public can punish in a disciplined, professionalized way. Some citizen policing programs may, for example, be unobjectionable, to the extent that those programs can succeed in inculcating norms of police behavior in the general public. I register my skepticism, though, that the public can ordinarily be trained to any appropriate level of discipline, especially when presented with the most garish of the newer shame sanctions. 